\title{
Groundwater dynamics in subterranean estuaries of coastal unconfined aquifers: Controls on submarine groundwater discharge and chemical inputs to the ocean
}

\author{
Clare E. Robinson', Pei Xin², Isaac R. Santos ${ }^{3}$, Matthew A. \\ Charette $^{4}$, Ling Li ${ }^{5}$, D. A. Barry \\ ${ }^{1}$ Department of Civil and Environmental Engineering, Western University, London, Canada \\ ${ }^{2}$ State Key Laboratory of Hydrology-Water Resources and Hydraulic Engineering, Hohai \\ University, Nanjing, China \\ ${ }^{3}$ National Marine Science Centre, Southern Cross University, Coffs Harbour, NSW, Australia \\ ${ }^{4}$ Department of Marine Chemistry and Geochemistry, Woods Hole Oceanographic Institution, \\ Woods Hole, Massachusetts, USA \\ ${ }^{5}$ School of Civil Engineering, The University of Queensland, Queensland, Australia \\ ${ }^{6}$ Laboratoire de technologie écologique (ECOL), Institut d'ingénierie de l'environnement (IIE), \\ Faculté de l'environnement naturel, architectural et construit (ENAC), Ecole Polytechnique \\ Fédérale de Lausanne (EPFL), Lausanne, Switzerland
}

Corresponding author: Clare E. Robinson, Department of Civil and Environmental Engineering, Western University, London, Ontario, Canada, N6A 5B9 (crobinson@eng.uwo.ca)

Accepted for publication in Advances in Water Resources on 30 October 2017 


\section{ABSTRACT}

Sustainable coastal resource management requires sound understanding of interactions between coastal unconfined aquifers and the ocean as these interactions influence the flux of chemicals to the coastal ocean and the availability of fresh groundwater resources. The importance of submarine groundwater discharge in delivering chemical fluxes to the coastal ocean and the critical role of the subterranean estuary (STE) in regulating these fluxes is well recognized. STEs are complex and dynamic systems exposed to various physical, hydrological, geological, and chemical conditions that act on disparate spatial and temporal scales. This paper provides a review of the effect of factors that influence flow and salt transport in STEs, evaluates current understanding on the interactions between these influences, and synthesizes understanding of drivers of nutrient, carbon, greenhouse gas, metal and organic contaminant fluxes to the ocean. Based on this review, key research needs are identified. While the effects of density and tides are well understood, episodic and longer-period forces as well as the interactions between multiple influences remain poorly understood. Many studies continue to focus on idealized nearshore aquifer systems and future work needs to consider real world complexities such as geological heterogeneities, and non-uniform and evolving alongshore and cross-shore morphology. There is also a significant need for multidisciplinary research to unravel the interactions between physical and biogeochemical processes in the STE, as most existing studies treat these processes in isolation. Better understanding of this complex and dynamic system can improve sustainable management of coastal water resources under the influence of anthropogenic pressures and climate change.

Keywords: groundwater-ocean interactions, nutrients, metals, organic contaminants, tides, waves, interacting effects 


\section{List of Acronyms}

CUA Coastal unconfined aquifer

DZ Dispersion zone

FSGD Fresh submarine groundwater discharge

SGD Submarine groundwater discharge

SLR Sea level rise

STE Subterranean estuary

USP Upper saline plume 


\section{Introduction}

Sustainable management of coastal marine and groundwater resources is a major global environmental challenge due to accelerating anthropogenic and climate pressures on coastal areas [Vörösmarty et al., 2000; Scavia et al., 2002; Ferguson and Gleeson, 2012]. Up to 1.4 billion people will live in low-elevation coastal zones with a flood frequency of 1 in $100 \mathrm{y}$ by 2060, representing a $120 \%$ increase in the coastal population since the year 2000 [Neumann et al., 2015]. Pressures associated with population growth and intensifying coastal development will be compounded by climate change effects including sea level rise (SLR) and the increasing frequency and intensity of coastal hazards (e.g., storm surges, hurricanes) [Bosello et al., 2007; McGranahan et al., 2007; Alongi, 2008; Halpern et al., 2008; Knutson et al., 2010; Hallegatte et al., 2011]. These pressures exacerbate the challenges inherent in sustainable management of coastal resources, and underscore the need for sound understanding of land-ocean interactions [Borja, 2005; Hamilton and Gehrke, 2005; Day et al., 2008], including the exchange of water and chemicals across the land-ocean interface. 


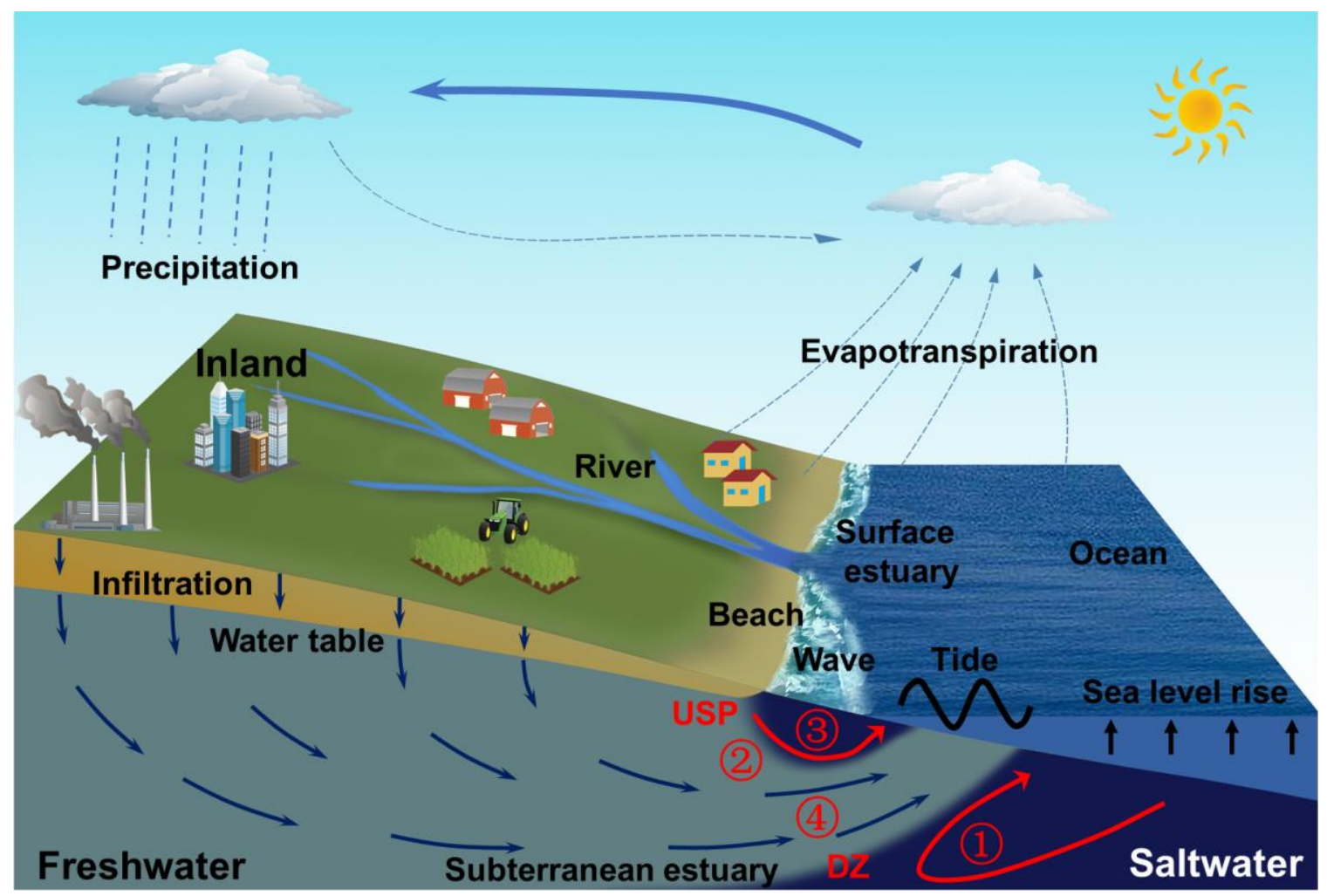

Figure 1. Conceptual diagram of a coastal unconfined aquifer (CUA) and subterranean estuary (STE), including major flow processes: 1) density-driven recirculation, 2) tide-induced recirculation, 3) wave-driven recirculation and 4) terrestrial fresh groundwater discharge. The STE is associated with the dispersion zone (DZ) of the saltwater wedge and the upper saline plume (USP).

Coastal unconfined aquifers (CUAs) are a key hydrogeological feature connecting the world's oceanic and groundwater resources. Beaches, which are globally the most common type of open shoreline, typically represent the seaward extent of CUAs [Defeo et al., 2009]. Understanding interactions between CUAs and the coastal ocean is critical for integrated resource management as these interactions control the exchange of water and chemicals across the land-ocean interface in both seaward and landward directions (Figure 1) [Leeks and Jarvie, 1998; Carabin and 
Dassargues, 1999; Alongi et al., 2004; Newton and Mudge, 2005]. From a terrestrial perspective, CUA-ocean interactions are important because they affect the availability of fresh groundwater in coastal areas, which can be threatened by seawater intrusion [Werner et al., 2013; Yu et al., 2016]. From a marine perspective, CUA-ocean interactions are important because they can impact coastal water quality and ecosystems due to the discharge of groundwater and associated chemicals to the coastal ocean [Moore, 2010].

Over the last $30 \mathrm{y}$, it has become well established that the total flux of water from coastal aquifers to the ocean (termed submarine groundwater discharge, SGD) is an important component of the hydrologic cycle and can be a major pathway for delivering chemicals across the land-ocean interface [Moore, 1996; Burnett et al., 2003; Moore, 2010]. Field investigations around the world have documented coastal settings where SGD is an important source of freshwater [Burnett et al., 2003; Burnett et al., 2006; Stalker et al., 2009; Wang et al., 2015], nutrients [Paytan et al., 2006; Shellenbarger et al., 2006; Lee et al., 2009; Luo et al., 2014], carbon [Cai et al., 2003; Goni and Gardner, 2003] and trace elements [Charette and Sholkovitz, 2006; Beck et al., 2007; Beck et al., 2010] into the coastal and open ocean. Defined as the total water efflux across the seabed to the ocean, SGD comprises terrestrial (fresh) groundwater discharge as well as all seawater recirculating across the sediment-water interface [Burnett et al., 2003]. While SGD also occurs across the continental shelf with water exchange driven by forces including geothermal heating and pressure gradients through discontinuous confining layers [Moore, 2010], this review focuses on SGD and associated chemical fluxes from CUAs to the nearshore zone. CUAs and associated ecosystems are highly vulnerable to anthropogenic and climate pressures and therefore focusing this paper on CUAs provides understanding required to protect coastal resources in light of this vulnerability. 
Wherever the groundwater table in a CUA is higher than the mean sea level, terrestrial fresh groundwater (also called fresh SGD, FSGD) discharges to the ocean. Seawater also intrudes into a CUA, forming a zone of saltwater-freshwater mixing in the aquifer. Due to the distinct chemical compositions of terrestrial groundwater and seawater, the saltwater-freshwater mixing zone is often characterized by strong geochemical (salinity, redox, $\mathrm{pH}$ ) gradients, making it an important chemical reaction zone [Moore, 1999; Charette and Sholkovitz, 2002]. In analogy to the classical (surface) estuary, the zone of saltwater-freshwater mixing in a CUA is termed a subterranean estuary (STE) [Moore, 1999]. By controlling the functioning of a STE, the groundwater flow, solute transport and reaction dynamics in the nearshore zone of a CUA (nearshore aquifer) affect the fate and flux of terrestrial chemicals discharging to the coastal ocean [e.g., Beck et al., 2007; Kroeger and Charette, 2008; Anwar et al., 2014]. They also affect the fate of marine-derived chemicals recirculating through a nearshore aquifer and subsequent chemical fluxes returned to the coastal ocean [e.g., Charette and Sholkovitz, 2006; Anschutz et al., 2009; Moore, 2010; Charbonnier et al., 2013].

The nearshore aquifer is a complex system that is exposed to various dynamic hydrological forces that act on a wide range of spatial and temporal scales [Santos et al., 2012c]. These forces include the terrestrial hydraulic gradient, tides, waves, seasonal and interannual sea level and aquifer recharge variations amongst others. Nearshore groundwater dynamics are further complicated by variable-density effects and local hydrologic processes including evaporation and rainfall. A simplified representation of the water exchange and groundwater flow processes in a CUA system exposed to various driving forces is shown in Figure 1. Additional complicating features including geological heterogeneities, and complex alongshore and cross-shore morphology are not shown in Figure 1, although their importance is discussed in this review. 
Smaller-scale water exchange processes including exchange induced by current-bedform interactions, bioirrigation and ripple migration are also not included. Santos et al. [2012b] recently reviewed these physical drivers for SGD.

Over the last decade, significant research effort has been devoted to better understanding the effect of the various driving forces on SGD and the functioning of a STE (flow, mixing and reaction processes) to better understand their impacts on chemical fluxes to the coastal ocean. Reviews are available that focus on SGD including the underlying mechanisms (i.e., driving forces) [Burnett et al., 2003; Santos et al., 2012b], associated chemical fluxes to the ocean [Slomp and Van Cappellen, 2004; Moore, 2010; Knee and Paytan, 2012] and measurement techniques [Burnett et al., 2001; Taniguchi et al., 2003]. Similarly, reviews that provide a synthesis of the growing number of SGD field studies are available [Taniguchi et al., 2002; Kwon et al., 2014; Cho and Kim, 2016]. Saltwater intrusion in coastal aquifers, a topic inextricably linked to nearshore groundwater dynamics and SGD, was extensively studied over the last 50 y with a comprehensive review recently provided by Werner et al. [2013]. The objective of this paper is to provide a review of the relative effects of the various physical forces on nearshore groundwater dynamics in CUAs, evaluate current understanding on the interactions between these forces, and synthesize conceptual models with respect to how nearshore groundwater dynamics impact chemical fluxes to coastal waters. Reviewing nearshore groundwater dynamics is relevant not only for understanding SGD and associated chemical fluxes to the coastal ocean, but also important for other coastal sub-discipline areas including coastal (beach) geomorphology, beach-scale hydrology and salinization of coastal groundwater resources (i.e., saltwater intrusion). We first synthesize current understanding with respect to the effect of the various driving forces on nearshore groundwater flow and salt transport (Section 2). 
Second, we review the behavior of nutrients, carbon, greenhouse gases, metals and organic contaminants in CUAs (especially the STE), and the ultimate flux of these chemicals to the coastal ocean (Section 3). Finally, key knowledge gaps and challenges that need to be addressed to advance understanding of this poorly quantified connection between the land and ocean are provided.

\section{Flow and salt transport under different drivers}

\subsection{Density}

The density difference between seawater and terrestrial fresh groundwater influences nearshore groundwater dynamics and contributes to the exchange of water across the CUA-ocean interface. Buoyancy forces associated with these density differences interact with advective forces associated with terrestrial groundwater discharge, dispersive processes and hydrogeological conditions to control the configuration of the saltwater wedge and associated density-driven flow and transport in a CUA [Werner et al., 2013]. As described by Cooper [1959], hydrodynamic dispersion across the interface (dispersion zone; DZ, Figure 1) of the saltwater wedge causes salt to move into the freshwater zone, driving convective recirculation within the saltwater wedge. This density-driven recirculation contributes to SGD [Destouni and Prieto, 2003; Smith, 2004].

It is challenging to determine the contribution of density-driven recirculation to total SGD from field data alone. Therefore, estimates often rely on numerical simulations. Early simulations by Destouni and Prieto [2003] suggested that the magnitude of density-driven recirculation is easily quantifiable, being a linear function of the FSGD. However, Smith [2004] presented a more extensive, non-dimensional parametric study showing that prediction of density-driven recirculation is strongly dependent on aquifer dispersivity, which is typically uncertain and 
highly scale dependent. Smith [2004] also showed that density-driven recirculation is greatest for medium FSGD rates because high FSGD reduces saltwater intrusion into the aquifer, whereas low FSGD leads to a wide DZ with reduced density gradients to drive recirculation. More recently Qu et al. [2014] showed numerically that the anisotropy ratio of horizontal to vertical hydraulic conductivity also influences density-driven recirculation with the saltwater wedge interface retreating seaward and density-driven recirculation decreasing as this ratio increases. The DZ of the saltwater wedge is an important mixing zone between terrestrial groundwater and recirculating seawater in a STE. The travel pathway and residence times for density-driven recirculation depends on the hydrogeology of the CUA but they are generally long with residences times varying from an order of $100 \mathrm{~d}$ to over tens of thousands of years [Robinson et al., 2007b; Post et al., 2013]. This provides significant time for reactions to occur including aquifer sediment transformations such as carbonate diagenesis [Back et al., 1979]. The location, shape and thickness of the DZ and thus configuration of the STE depend on various factors including the aquifer dispersivity, FSGD and the density contrast between the seawater and terrestrial groundwater [e.g., Volker and Rushton, 1982]. The DZ is also influenced by transient forcing such as sea level and seasonal recharge variations and therefore it is rarely at steady state [Michael et al., 2005; Gonneea et al., 2013b]. These transient effects including implications for the extent of saltwater-freshwater mixing in a STE are described in the following sections.

\subsection{Recharge}

Recharge to a CUA and subsequent FSGD is a primary component of SGD and driver of chemical flux across the land-ocean interface (Figure 1). Global water budget and integrated hydrologic-hydrogeological approaches suggest FSGD may account for 0.3 to $16 \%$ of the total freshwater discharge to oceans [Zektser and Loaiciga, 1993; Burnett et al., 2003]. FSGD is 
highly variable at small and large scales, and depends on various geological, hydrological and climate factors. While numerous small-scale field measurement techniques (e.g., seepage meters and tracers) are available, it remains a challenge to identify coastal areas with high FSGD at larger scales (i.e., continental, global). Bokuniewicz et al. [2003] developed a clustering analysis tool to help identify coastal areas with potential for high FSGD based on relevant hydrological parameters, however the typology model lacks quantification of key controlling parameters. More recently, Sawyer et al. [2016] identified areas along the United States coastline vulnerable to high FSGD based on water budget analysis combined with continental scale hydrography and climate data sets. They defined recharge zones for FSGD as areas outside stream catchments where groundwater flows directly to the coast. SGD studies have traditionally been dominated by oceanographers using tracer-based approaches. It is, however, challenging to separate the respective contributions of FSGD and saline SGD (i.e., seawater recirculation) to total SGD even with the use of multiple tracers (radon, radium, methane, salinity, etc.) [e.g., Cable et al., 1996; Santos et al., 2009b; Santos et al., 2009c]. Large discrepancies between tracer-based and inland hydrology-based estimates (e.g., seepage meters, water budgets) of FSGD are still often observed [Destouni and Prieto, 2010] in part because different techniques quantify different components of SGD. While understanding of nearshore groundwater dynamics can provide important insight into total SGD rates to the coastal ocean, there is a need to better rectify the consistency between these approaches.

Advective transport associated with FSGD affects nearshore groundwater dynamics with the balance between inland (recharge) and oceanic (tides, waves) forces controlling water exchange rates across the CUA-ocean interface, and the salt distribution and extent of saltwater-freshwater mixing in a STE. The interactions between inland and oceanic forces are described further in 
Sections 2.3 and 2.4. The inland advective force also acts against the buoyancy force associated with density gradients in a CUA - this determines the extent of seawater intrusion in the aquifer. When FSGD is low, the CUA may be more vulnerable to saltwater intrusion, and vice versa [Glover, 1959; Sawyer et al., 2016]. Understanding the relationship between the vulnerability of coastal waters to the consequences of FSGD versus a CUAs vulnerability to saltwater intrusion is essential for integrated coastal resource management.

Recharge to CUAs often varies seasonally leading to seasonal variations in FSGD [Michael et al., 2005; Charette, 2007; Miyaoka, 2007; Moore, 2007; Loveless et al., 2008; Sugimoto et al., 2016]. Seasonal recharge patterns also cause the $\mathrm{DZ}$ of the saltwater wedge to oscillate landward and seaward [Michael et al., 2005]. Michael et al. [2005] showed that these oscillations can lead to seasonal discharge of saline water from a CUA. Seasonal oscillations in the DZ location can also lead to significant widening of the DZ and thus expansion of the STE particularly in more heterogeneous aquifers and where salt gets trapped in non-mobile pores [Lu et al., 2009]. Recently Yu et al. [2017] explored the effects of episodic rainfall events, illustrating the delayed and cumulative effect of episodic rainfall events on SGD and movement of the saltwater wedge. They further showed that a generalized linear model with past rainfall events weighted in the form of a convolution may be a valuable approach for evaluating and predicting the SGD, movement of the saltwater wedge and associated mass fluxes a STE.

\subsection{Tides}

Tides are an important oceanic force along most coastlines worldwide. Early work examining the influence of tides on groundwater dynamics in CUAs focused mainly on tide-induced watertable fluctuations [e.g., Lanyon et al., 1982; Parlange et al., 1984; Nielsen, 1990; Li et al., 2000]. 
However, over the last decade major research efforts were devoted to understanding the influence of tides on water exchange across the CUA-ocean interface, and the flow and saltwater-freshwater mixing in a STE.

Tidal fluctuations drive large quantities of water exchange across the CUA-ocean interface as seawater fills and drains from the nearshore aquifer over a tidal cycle. Field and numerical studies quantified the tidal effect on SGD and showed that tide-induced recirculation can represent a major portion of total SGD [e.g., Li et al., 1999; Taniguchi, 2002; Robinson et al., 2007c; Li et al., 2009]. Seawater infiltration into an aquifer occurs on the rising tide and exfiltration (saline SGD) on the ebbing tide [Robinson et al., 1998; Sholkovitz et al., 2003; Robinson et al., 2007c]. As a nearshore aquifer is able to fill faster than it can drain, infiltration is greatest from the mid-tide to high tide mark and exfiltration is greatest towards the low tide mark [Robinson et al., 2007b]. Further, there is an asymmetry in the groundwater table fluctuations (rising quickly and falling slowly) that is enhanced by a sloping beach face [Nielsen, 1999; Li et al., 2000]. The asymmetry leads to an overheight in the groundwater table near the shoreline, i.e., tidally-averaged watertable at the shoreline is higher than the mean sea level [Parlange et al., 1984; Nielsen, 1990]. For a CUA with a fixed inland head this may reduce FSGD to the coastal ocean.

When the instantaneous tide-induced water exchange and groundwater flows are averaged over a tidal cycle, seawater recirculation extends across the intertidal zone. This time-averaged circulating flow can lead to the formation of an upper saline plume (USP, Figure 1) [Robinson et al., 1998; Boufadel, 2000; Mango et al., 2004; Vandenbohede and Lebbe, 2005; Robinson et al., 2007b]. Where the USP is present, FSGD travels below the USP and discharges near the low tide mark in a zone bounded by the USP and the saltwater wedge. Numerous field, numerical and 
laboratory studies have observed this salinity distribution in tidally-influenced CUAs [e.g., Lebbe, 1981; Boufadel, 2000; Mango et al., 2004; Vandenbohede and Lebbe, 2005; Boufadel et al., 2006; Mao et al., 2006; Robinson et al., 2006; Robinson et al., 2007b; Yang et al., 2013; Buquet et al., 2016]. The USP, in comparison with the DZ of the saltwater wedge, is a more active zone of saltwater-freshwater mixing in a CUA and an important feature of the STE system [Robinson et al., 2007b; Thorn and Urish, 2013].

The USP does not exist in all tidally-influenced CUAs. Its presence depends on magnitude of advective forces associated with terrestrial groundwater discharge (FSGD) to tidal forces (or tidal amplitude) [Robinson et al., 2007b], as well as physical parameters including beach morphology, aquifer hydraulic conductivity, aquifer anisotropy and heterogeneity, and dispersivity [Mao et al., 2006; Li et al., 2008; Li et al., 2009; Boufadel et al., 2011; Abarca et al., 2013; Evans and Wilson, 2016; Li et al., 2016]. Figure 2 illustrates the effects of FSGD on extent of the USP and saltwater-freshwater mixing in the STE under the same tidal conditions. In analogy to the surface estuary classification, Robinson et al. [2007b] proposed a classification system for a tidally-influenced STE. They showed that the balance of the inland (FSGD) forces to tidal forces is an important control on a STE with the ratio of FSGD to the tide-induced saline SGD affecting the extent of stratification in a tidally-influenced STE (i.e., stratified, partially stratified or well-mixed; see examples in Figure 2). The challenge with this classification system is that there is currently no simple approach to predict tide-induced SGD rates. Robinson et al. [2007c] presented a non-dimensional analysis to evaluate how various parameters impact tideinduced SGD for homogeneous, isotropic CUAs; however, the number of simplifications made in this study is likely to limit the general applicability of the findings. 

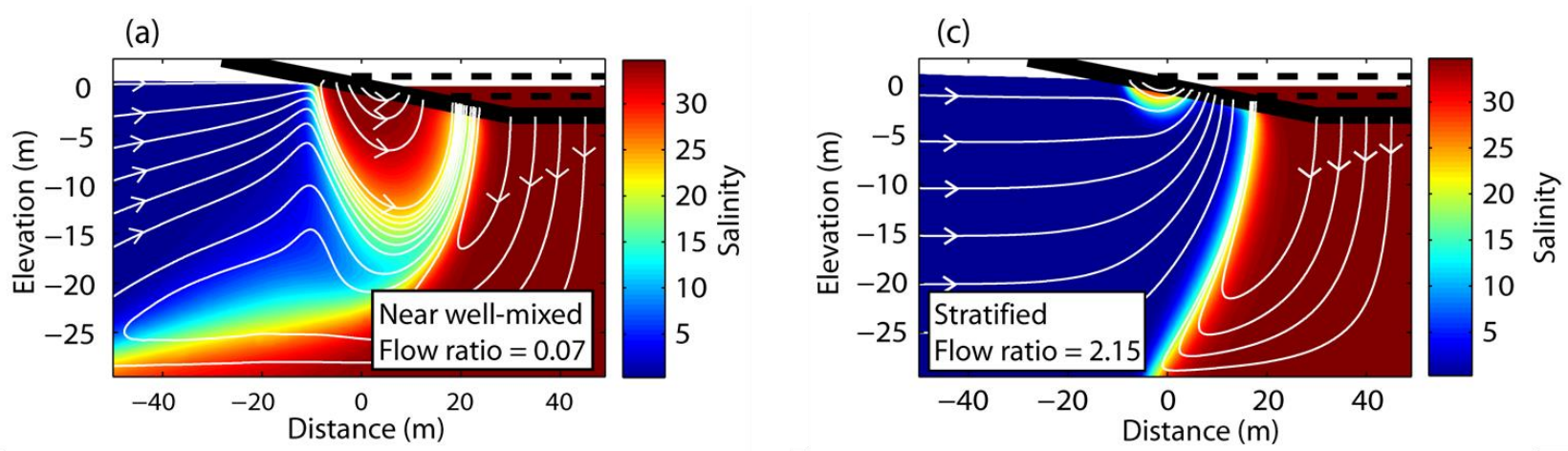

(b)

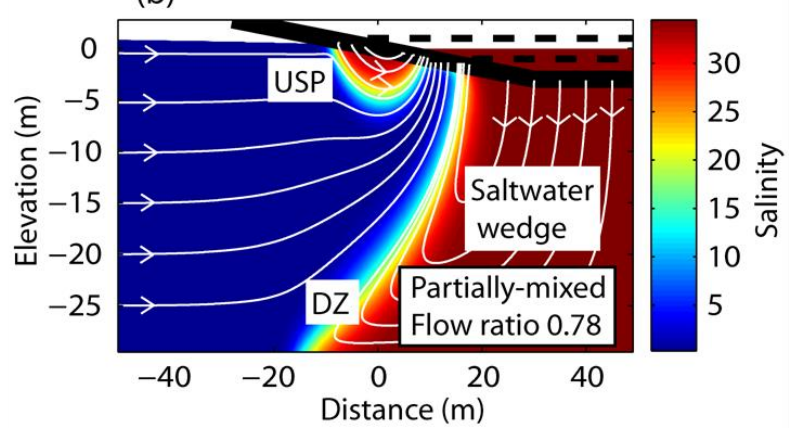

(d)

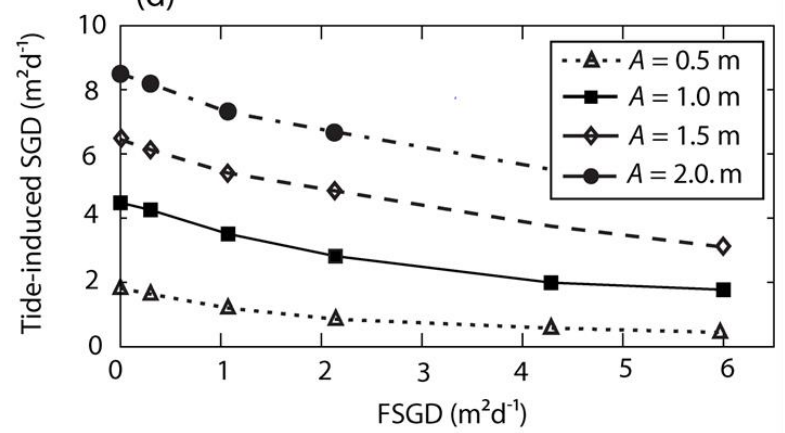

Figure 2. Simulated salinity (colored contours) and flow streamlines in tidal-influenced CUAs with varying stratification (mixed, partially-mixed, stratified). (a) FSGD $=0.3 \mathrm{~m}^{2} \mathrm{~d}^{-1}$ and tidal amplitude $(A)=1 \mathrm{~m}$; (b) FSGD $=2.1 \mathrm{~m}^{2} \mathrm{~d}^{-1}$ and $A=1 \mathrm{~m}$; and (c) FSGD $=4.3 \mathrm{~m}^{3} \mathrm{~d}^{-1}$ and $A=1$ m. The flow ratio is defined as the ratio FSGD to tide-induced SGD. The black dashed horizontal lines in (a) - (c) indicate the high tide and low tide levels. Simulation results illustrating how tide-induced SGD is controlled by FSGD for a given tidal amplitude $(A)$ is shown in (d). Information on the numerical simulations is provided in Robinson et al. [2007b].

While advective transport associated with the tide-induced circulations and FSGD leads to the formation of an USP, recent studies have shown that gradients arising from denser saltwater overlying less-dense fresh groundwater may lead to flow instabilities in the form of salt fingering [Greskowiak, 2014; Röper et al., 2015]. Greskowiak [2014] showed numerically that flow instabilities are more likely to occur as the ratio of density gradient to the ambient flow (driven by tidal fluctuations and seaward hydraulic gradient associated with FSGD) increases. Röper et 
al. [2015] later used laboratory sand flume experiments to confirm that instabilities can form under low beach slope. While Rapaglia and Bokuniewicz [2009] provided field data suggesting potential salt fingering in the subtidal zone near the shoreline, the formation of instabilities within the intertidal zone is yet to be observed. The complex flows and salt transport associated with instabilities may, however, considerably increase saltwater-freshwater mixing in a STE as well as locations where fresh groundwater discharges along the intertidal zone (i.e., discharge may no longer occur predominately near the low tide mark) [Greskowiak, 2014; Röper et al., 2015].

In addition to altering the shallow nearshore salinity distribution in a CUA, tidal effects also modify the configuration of the saltwater wedge and mixing along the DZ. Ataie-Ashtiani et al. [1999] and Chen and Hsu [2004] simulated the effect of tides on seawater intrusion in CUAs and found that tides force saltwater to intrude further inland and widen the DZ. These studies were based on simulations of shallow CUAs with relatively high ratios of tidal amplitude to aquifer depth. Kuan et al. [2012] illustrated through numerical modelling combined with laboratory experiments that in tidally-influenced aquifers where an USP forms, the extent of seawater intrusion into the aquifer is significantly reduced compared to non-tidal conditions. More recently, Pool et al. [2014] and Pool et al. [2015] conducted numerical analyses to quantify the effect of tides on the saltwater wedge DZ in homogeneous and heterogeneous CUAs. They showed the extent of mixing is influenced by the tidal amplitude, tidal period and hydraulic diffusivity, with the aquifer heterogeneity reducing the impact of tides on the extent of mixing along the DZ.

The tide-induced USP is associated with considerably shorter flow paths and residence times compared to recirculation through the saltwater wedge. Understanding the residence time of 
seawater circulating through these saline zones is important because it determines, in part, the extent to which different geochemical reactions may take place. Numerical work by Robinson et al. [2007b] showed that for the sandy nearshore aquifer simulated, the average residence time of seawater recirculating through the USP was in the order of $10 \mathrm{~d}$ compared with over $1000 \mathrm{~d}$ for the saltwater wedge. More recently, Tamborski et al. [2017] found residence times in the intertidal zone to range from 0.1 to more than $15 \mathrm{~d}$ using pore water measurements of ${ }^{222} \mathrm{Rn}$ and ${ }^{224} \mathrm{Ra}$ across the intertidal zone of two beaches together with a one-dimensional advection model.

While most studies focus on the effect of semi-diurnal and diurnal tides on groundwater dynamics, the variation in tidal ranges over the spring-neap period also considerably affects the flow and salt transport within a STE. Fluctuations in SGD in response to the spring-neap tidal cycle has been widely reported [Kim and Hwang, 2002; Taniguchi, 2002; Taniguchi et al., 2006; Robinson et al., 2007a; de Sieyes et al., 2008; Wilson et al., 2015]. While the salt distribution in a STE (including the configuration of an USP) typically does not oscillate considerably in response to semi-diurnal or diurnal tides (except for high permeability gravel beaches [Guo et al., 2010; Geng and Boufadel, 2017]), it does vary in response to the spring-neap signal. The expansion and contraction of the USP as the spring and neap tides approach, respectively, were observed experimentally for microtidal and macrotidal beaches [Robinson et al., 2007a; Abarca et al., 2013; Heiss and Michael, 2014; Buquet et al., 2016]. Abarca et al. [2013] also showed the complex interactions of the flows and salinity distribution with changes in the cross-shore beach morphology over the spring-neap cycle. Aside from this study, the effects of varying beach morphology are not well quantified although they may considerably affect the flows and saltwater-freshwater mixing in a STE. This may in part be due to the difficulty with measuring 
and numerically simulating this effect as well as disentangling it from other dynamic forcing effects (i.e., spring-neap signal, waves).

Studies investigating the effects of tides on nearshore groundwater dynamics typically focus on evaluating characteristics and processes in the cross-shore direction and assume negligible alongshore variability. As such, numerical groundwater models used to quantify tidal effects are often two-dimensional (neglect alongshore variations) [e.g., Boufadel, 2000; Robinson et al., 2007b; Evans and Wilson, 2016], and field studies typically aim to obtain data along a single cross-shore monitoring transect [e.g., Michael et al., 2005; Robinson et al., 2006; Abarca et al., 2013]. Alongshore variations associated with, for instance tidal creeks, headlands and embayments and geological heterogeneities are common, but the three-dimensionality of the nearshore groundwater system is not well understood. Zhang et al. [2016] showed complex three-dimensional flows and salt transport in a CUA at a field site located adjacent to a tidal creek with strong alongshore morphology variations. Russoniello et al. [2013] illustrated the importance of small-scale submarine geological heterogeneities in controlling SGD and salt transport patterns. The three-dimensional flow and salt transport characteristics revealed in these studies are likely to be present along many natural coastlines.

\subsection{Waves}

In addition to tides, waves are also an important oceanic force acting on most shorelines worldwide. Evaluating the effect of waves on groundwater dynamics is arguably more difficult than evaluating the effect of tides as wave forcing is highly irregular and acts on multiple time scales. While wave periods typically range from a few to tens of seconds in the nearshore zone, wave height also varies over long time scales with intensified wave conditions occurring, for 
instance, in response to offshore storms. Waves drive large volumes of water exchange across the CUA-ocean interface [Li et al., 1999]. It is challenging to quantify wave-driven recirculation from field data alone, but estimates have been provided through numerical studies [e.g., Xin et al., 2010; Bakhtyar et al., 2011; Geng et al., 2014; Robinson et al., 2014; Xin et al., 2014]. Wave-driven recirculation generally constitutes a considerable portion of the total SGD along wave-influenced coasts although the rates vary depending on the physical characteristics of the coastal setting (e.g., beach slope, hydraulic conductivity) as well as the magnitude of the wave forcing (i.e., wave height and frequency) and FSGD.

Individual waves lead to oscillating infiltration-exfiltration across the CUA-ocean interface at high frequency (Figure 3). The dynamics of this rapid infiltration-exfiltration have been studied with respect to its effect on beach sediment transport and coastal morphology [e.g., Turner and Nielsen, 1997; Horn et al., 1998; Masselink and Hughes, 1998; Turner and Masselink, 1998; Baldock et al., 2001; Elfrink and Baldock, 2002; Horn, 2006; Bakhtyar et al., 2012]. Heiss et al. [2014] presented field measurements to quantify infiltration into the unsaturated zone as individual waves run up and down on the shoreline (Figure 3). Apart from this study and a few others including laboratory experiments [Boufadel et al., 2007; Heiss et al., 2015; Malott et al., 2016; Sous et al., 2016; Turner et al., 2016; Malott et al., 2017], investigations of wave-induced water exchange and groundwater dynamics have mostly been based on numerical simulations due to the challenge of measuring wave-induced groundwater flows in the field, including how to decouple wave and tide effects. Simulation of wave hydrodynamics coupled with densitydependent groundwater flow is computationally challenging but has been attempted by Bakhtyar et al. [2012] and Geng et al. [2014], who solved the Reynolds-Averaged Navier-Stokes (RANs) equations to simulate wave motion across a permeable beach surface. Both studies illustrate the 
complexity of wave-induced groundwater flows induced by individual waves with Bakhtyar et al. [2012] also demonstrating the additional impact of waves on beach morphology changes (e.g., wave-driven erosion/accretion).

The influence of high frequency individual waves gets rapidly damped with distance from the shoreline and with depth [Li and Barry, 2000]. The phase-averaged effect of waves has a more extensive impact on overall groundwater dynamics in a CUA. The energy dissipation and changes in the onshore radiation stress as a wave breaks leads to an onshore upward tilt in the mean sea level referred to as wave setup (Figure 3). Longuet-Higgins [1983] demonstrated analytically that the phase-averaged water level profile of wave set-up drives a flow circulation through the nearshore aquifer that extends from the wave set-up limit to the wave breaking point (Figure 3). Li and Barry [2000] showed that the magnitude of the phase-averaged circulating flow depends on the relative strength of inland forcing (i.e., inland hydraulic gradient, FSGD) relative to the wave forcing - a similar inland and oceanic force balance to that in the tidal case. Xin et al. [2010] used a density-dependent groundwater flow model with wave hydrodynamics simulated using the shallow water equations to show that the seawater circulation driven by wave setup leads to the formation of an USP similar to that formed due to tides. They also demonstrated that the effect of waves on groundwater dynamics including infiltration/exfiltration rates, salinity distribution and saltwater-freshwater mixing are mainly due to wave setup. Thus, the key effects of waves on a STE can be captured using a phase-averaged modelling approach of applying time-averaged heads describing wave setup along the seaward boundary rather than simulation of instantaneous waves. This phase-averaged approach is valuable for simulating the effects of variable wave forcing on nearshore groundwater dynamics because simulation of individual waves over long time scales is computationally demanding. Recently, Malott et al. 
[2016] validated the phase-averaged approach by comparing numerical simulation results with field data of pressure gradients in the swash zone over an isolated period of intensified wave conditions. Sous et al. [2016] also provided field evidence of wave-induced recirculation through the saturated zone of a beach aquifer. Geng and Boufadel [2015b] developed an alternative phase-averaged approach, in which the net influx-efflux across the CUA-aquifer boundary was determined from computationally intensive phase-resolved wave simulations and used to specify the boundary condition for density-dependent groundwater flow and solute transport simulations.

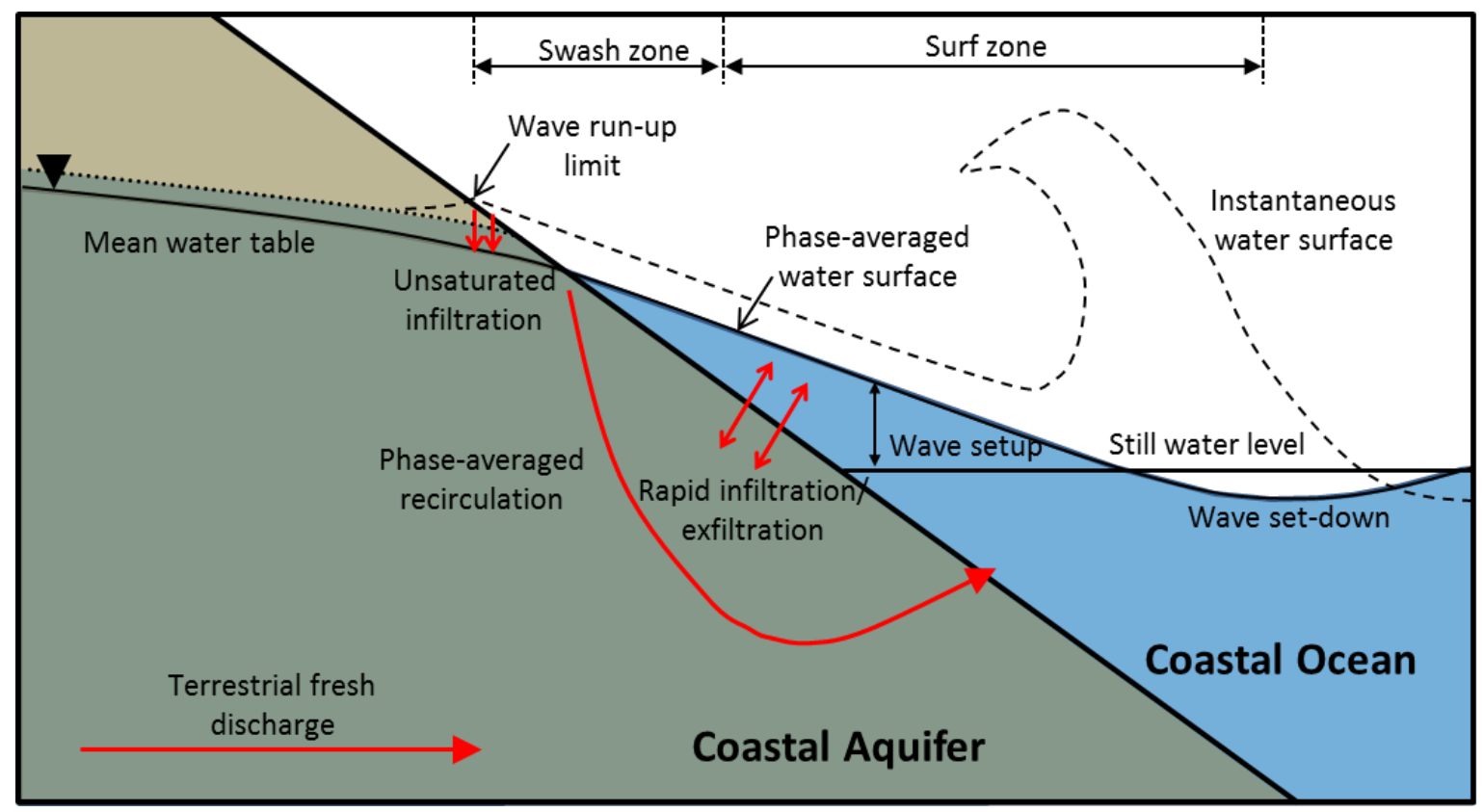

Figure 3. Conceptual diagram of the effect of waves on water exchange and groundwater flows in a nearshore aquifer including the phase-averaged effect of wave set-up, which drives a phaseaveraged circulation through the aquifer. The figure is not to scale. In natural systems, the beach profile is non-planar and evolving (erosion/accretion), which would further complicate the flow dynamics depicted here. This figure is modified from Malott et al. [2017]. 
Wave forcing along natural coastlines is highly variable with wave heights changing over time. The USP expands and contracts in response to the changing wave conditions, causing considerable saltwater-freshwater mixing in a STE [Robinson et al., 2014]. Robinson et al. [2014] simulated an isolated period of intensified wave conditions with a storm surge. The simulations showed that while the USP rapidly expands as the wave height increases, it may take $\sim 100 \mathrm{~d}$ for the salinity distribution in the STE to recover to its initial pre-storm state after the waves subside. The slow recovery of the aquifer salt distribution needs to be considered in field data interpretation as many field studies only take snapshot distributions of the salt distribution and geochemistry in a STE, thus ignoring the effects of antecedent wave conditions. Xin et al. [2014] examined the effects of variable wave forcing on water and salt fluxes across the CUAocean interface by considering year-long random wave data. They showed a retarded and prolonged response of SGD to the irregular wave conditions, suggesting that the present SGD depends on both the present and past wave conditions. Based on functional data analysis [Ramsay and Silverman, 2005], Xin et al. [2014] suggested that the historic wave effect can be quantified using a Gamma distribution. This analysis approach adopted forms a sound basis for quantifying and predicting SGD induced by irregular forcing conditions.

In addition to effects of variable wave forcing, large episodic wave events where the coastal plain is overtopped and inundated by seawater have a significant and long lasting (order of years) influence on the flows and salinity distribution in a CUA [Anderson and Lauer, 2008; Smith et al., 2008; Santos et al., 2009a; Yang et al., 2013; Yu et al., 2016]. Yu et al. [2016] showed numerically the important role of coastal topographic features in controlling the amount of seawater that infiltrates into the CUA when seawater inundation occurs and the length of the recovery time afterwards. Anderson and Lauer [2008] suggested that due to the long-lasting 
effects, episodic overtopping events can be a major controlling factor for saltwater-freshwater

mixing in STEs on micro-tidal barrier islands. Further, studies suggest that CUAs could be more threatened by overland seawater inundation rather than lateral saltwater intrusion (i.e., saltwater wedge) in the future as the climate changes [Ferguson and Gleeson, 2012; Holding and Allen, 2015].

\subsection{Evaporation}

Evaporation, as an important driving force for salt accumulation in soils, has been widely explored in inland groundwater systems due to its important ecological impact on plant growth, productivity and distribution [Penman, 1948; Brutsaert, 2005]. In contrast, the effects of evaporation on pore-water flow and salt transport in CUAs have attracted limited attention. As the CUA-ocean interface gets periodically inundated by tides and waves, different stages of evaporation can take place at various spatial and temporal scales [Idso et al., 1974; Brutsaert, 2005; Shokri and Or, 2011]. Geng and Boufadel [2015a] and Geng et al. [2016a] found that the evaporation rate in beaches depends on the local groundwater depth and mainly occurs in the intertidal zone. For the large area landward of the intertidal zone, the shallow sand layer above the watertable is relatively dry with a weak capillary transport capacity, not able to support a large evaporation flux. In the intertidal zone, the evaporation rate varies in response to tidal fluctuations. The evaporation takes away freshwater, decreasing the local water saturation and leaving salt behind in the shallow sand layer. Thus, evaporation leads to salt accumulation and higher pore-water salinity than seawater salinity particularly in the upper intertidal zone [Geng and Boufadel, 2015a]. The high pore-water salinity in the shallow sand layer may lead to formation and penetration of salt fingers into the beach that act to remove salt from the shallow sediment [Geng and Boufadel, 2015c; Xin et al., 2017]. Alternatively, if evaporation occurs 
continuously with no mechanism of salt removal, pore-water salinity would keep increasing. Once the saturated salinity level is reached, salt precipitation can occur in the shallow sand layer, which would in turn reduce evaporation from the sand [Nachshon et al., 2011; Zhang et al., 2014]. Despite these studies exploring the effects on evaporation on the salinity distribution in shallow STE sediments, the importance of these effects on the flows and saltwater-freshwater mixing in a STE remains unclear.

\subsection{Sea level changes}

Global sea level is predicted to rise between $0.26-0.82 \mathrm{~m}$ by the year 2100 in response to climate change [International Panel on Climate Change, 2013]. Sea level rise (SLR) will alter the hydrological balance between the land and ocean, leading to changes in the exchange of water and chemicals across the CUA-ocean interface, and flows and salt distribution within a CUA. The effects of SLR on seawater intrusion in CUAs (i.e., movement of saltwater wedge) has been well studied due to the potential threat to fresh coastal groundwater resources [Ferguson and Gleeson, 2012; Werner et al., 2013; Ketabchi et al., 2016]. The effects of SLR on seawater intrusion vary depending on the hydrological and geological characteristics of a CUA. A key factor is whether a CUA can be classified as a flux-controlled system, where FSGD to the sea is constant, or a head-controlled system where the inland watertable head is constant despite SLR [Werner and Simmons, 2009; Michael et al., 2013; Ketabchi et al., 2016]. Head-controlled systems are more vulnerable to SLR [Werner and Simmons, 2009]. The rise in sea level leads to a decrease in the regional hydraulic gradient and thus FSGD, which would intensify seawater intrusion into the aquifer. Head-controlled systems are also more often found in low-lying coastal areas where overland sea inundation is more likely to occur - this may also rapidly increase the extent of seawater intrusion [Ketabchi et al., 2016]. SGD and seawater intrusion are 
complementary processes. Michael et al. [2013] demonstrated numerically that changes in FSGD and density-driven SGD may be negligible in response to SLR in flux-controlled CUAs, but both FSGD and saline SGD may considerably decrease in head-controlled CUAs. They also showed that SLR may lead to a thickening of the saltwater wedge DZ, and thus widening of the STE, in head-controlled systems. Of course, other long-term anthropogenic pressures on CUAs will also affect the hydrological balance between the CUA and ocean. For instance, changing local net aquifer recharge or groundwater withdrawals (pumping) from CUAs may have a greater influence on seawater intrusion and SGD than SLR [Kundzewicz and Doli, 2009; Yechieli et al., 2010].

The effects of SLR on nearshore groundwater flows and salt-freshwater mixing in a STE has been less studied than the effects on seawater intrusion. It is possible that for a head-controlled CUA, the decrease in hydraulic gradient and thus FSGD (i.e., inland forces) relative to the oceanic forces could increase tide- and wave-induced recirculation [Kuan et al., 2012]. SLR could also alter the wave motion and tidal fluctuations along shorelines, which would subsequently alter water exchange rates, and groundwater flows and saltwater-freshwater mixing in a STE. These long-term changes have not yet been investigated.

In addition to long-term SLR, seasonal and interannual variability in mean sea level can also affect SGD rates and mixing within a STE. This was illustrated in a multi-year study conducted by Gonneea et al. [2013b] in a STE in Waquoit Bay, Massachusetts. They showed that seasonal sea level variations caused by the annual solar tide component and thermosteric sea level variability, and interannual sea-level variations associated with climate oscillations (i.e., North Atlantic Oscillation and El Niño Southern Oscillation), were the largest contributor to temporal variations in hydraulic gradient across the CUA and therefore SGD. This contrasts with other 
studies [e.g., Michael et al., 2005; Anderson and Emanuel, 2010] that showed seasonal and interannual variations in coastal hydraulic gradient and SGD to be largely controlled by inland groundwater level changes. Gonneea et al. [2013b] also observed the saltwater wedge DZ to oscillate landward and seaward in response to the sea level variations with simulations showing subsequent changes in saline SGD rates. The findings from Gonneea et al. [2013b] indicate that predicted future changes in regional climate variability may be important for saltwaterfreshwater mixing dynamics in STEs and SGD rates.

\subsection{Interacting effects among forcing}

In early work, SGD was taken to be a linear sum of (independent) fluxes estimated based on the various inland and oceanic forces [Li et al., 1999; Taniguchi et al., 2002; Burnett et al., 2006]. Indeed, these forces and associated fluxes have been often studied numerically in isolation as discussed earlier. For example, most research assessing coastal seawater intrusion focuses on inland freshwater input and neglects the dynamic oceanic forcing factors [Werner et al., 2013].

Most shorelines are exposed to multiple forcing factors, e.g., terrestrial freshwater discharge, density gradients, tides with multiple periodic constituents and irregular and random waves. As SGD includes all effluxes across the seabed, measured SGD from tracer-based investigations often includes the effects of multiple forcing factors [Santos et al., 2009c], although in some cases one forcing may dominate over others. For example, Heiss and Michael [2014] conducted a year-long field investigation on a microtidal sandy beach and found that the seawater recirculation, USP and configuration of the saltwater-freshwater mixing zone were affected mostly by seasonal recharge and to a lesser extent by tidal amplitude and tidal stage. Wilson et al. [2015] conducted a year-long field investigation on a muddy marsh with limited terrestrial 
freshwater input. They found, in contrast, SGD to be proportional to tidal amplitude, varying by at least a factor of two between spring and neap tides.

Interactions among the different forces are generally nonlinear [King, 2012; Geng and Boufadel, 2015b; Xin et al., 2015; Yu et al., 2017], in which case SGD is not a sum of independent terms. As described in Section 2.3, Robinson et al. [2007b] showed that tides can enhance the saltwaterfreshwater mixing along the saltwater wedge DZ, increasing the density-driven circulation and saline SGD. On the other hand, an increased FSGD can inhibit tide-induced and density-driven SGD. Xin et al. [2010] demonstrated that the effects of tides and waves do not simply add up, and the total saline SGD under the combined influence of tides and waves is less than the saline SGDs driven by tides and waves separately. The non-linear interactions among different forces acting on CUAs occur at different spatial as well as temporal scales. Both SGD and the salt distribution attributed to a particular force must be determined with consideration of the influence of other forces both at the present and in the past. The response of SGD and saltwaterfreshwater mixing zone to the different forces is not instantaneous but delayed [Michael et al., 2005; Lu and Werner, 2013; Heiss and Michael, 2014; Robinson et al., 2014; Xin et al., 2014; Liu et al., 2016; Yu et al., 2017]. This complicates the assessment of interactions between multiple forces. Via field investigations, Michael et al. [2005] revealed a time lag between changes in saline SGD rates, movement in the DZ, and the seasonal oscillations of inland recharge. Heiss and Michael [2014] examined saltwater-freshwater mixing dynamics in a sandy nearshore aquifer over tidal, spring-neap, and seasonal cycles. A time lag of the saltwaterfreshwater mixing zone was detected in response to the various forces. Xin et al. [2015] suggested that tides can increase the total SGD but concurrently weaken the delayed effect of waves on SGD. In contrast, tides enhance saltwater-freshwater mixing and strengthen the delay 
in the effect of waves on the salt fluxes across the CUA-ocean interface. This delays the return of the salt distribution in a STE to pre-storm conditions following a period of intensified wave conditions.

\section{Impact of the STE on chemical inputs to the ocean}

\subsection{Nutrients, carbon and greenhouse gases}

Since early suggestions that groundwater may be a major source of nutrients to the ocean [Johannes, 1980], a number of field investigations have demonstrated the biogeochemical implications of SGD. While the earlier SGD literature focused on nutrient fluxes, in the last few years there has been increased research on carbon cycling and the biological implications of SGD. The contribution of groundwater as a source of nutrients and carbon to the coastal ocean depends not only on the terrestrial groundwater composition, but also on biogeochemical processes within the STE [Anschutz et al., 2009]. The high microbial activity in nearshore aquifers due to the large inputs of water, solutes and organic matter from multiple sources makes the STE a unique biogeochemical reactor [Moore, 1999]. The biogeochemistry of a STE is often more dominated by anoxic pathways than surface estuaries. The more reducing conditions in a STE lead to SGD often having much higher proportions of bioavailable ammonium than the less available dissolved organic nitrogen (DON) that dominates river nitrogen $(\mathrm{N})$ inputs to the coastal ocean [Santos et al., 2014]. Understanding nutrient speciation and ratios is important as it determines the biological implications of SGD. Because phosphorus $(\mathrm{P})$ is typically more particle-reactive than $\mathrm{N}$ and therefore less mobile in groundwater, $\mathrm{SGD}$ often has $\mathrm{N}: \mathrm{P}$ ratios well above the ratio required by marine primary producers (i.e., N:P > 16). It has been suggested that high N:P ratios in contaminated SGD could drive the coastal ocean towards P-limitation within the coming decades, changing its current N-limited status [Slomp and Van Cappellen, 2004]. 
This model-based prognosis was confirmed experimentally in recent field studies with observations of high N:P ratios in SGD [Su et al., 2011; Lee et al., 2012; Santos et al., 2013; Santos et al., 2014].

Several studies emphasize that SGD is a major source of $\mathrm{N}$ and $\mathrm{P}$ to the coastal ocean and possibly an overlooked driver of eutrophication [e.g., Hu et al., 2006; Lee et al., 2010]. Other studies highlight that biogeochemical processes occurring in a STE can attenuate high $\mathrm{N}$ and $\mathrm{P}$ in contaminated terrestrial groundwater prior to discharge to the coastal ocean [Addy et al., 2005; Kroeger and Charette, 2008; Santoro et al., 2008]. For example, attenuation of nitrate contamination in terrestrial groundwater by denitrification has been observed in STEs [Loveless and Oldham, 2010; Weinstein et al., 2011; Erler et al., 2014], resulting in non-conservative net nitrate removal (Figure 4A). However, studies have also shown net nitrate production and high nitrate concentrations in shallow STEs despite low nitrate concentrations in both terrestrial groundwater and seawater. This is linked to high seawater recirculation (i.e., due to tides or waves) through the shallow STE combined with non-conservative net nitrate production by the mineralization of organic matter (Figure 4B) [Tait et al., 2014; Santos et al., 2009d]. The transformation of nutrients is affected by the reaction rates and residence times, which are controlled by the flow and transport processes driven by the various forces discussed in Section 2. Little information is available on biogeochemical reaction rates and residence times in STEs [Ibánhez and Rocha, 2017]. 

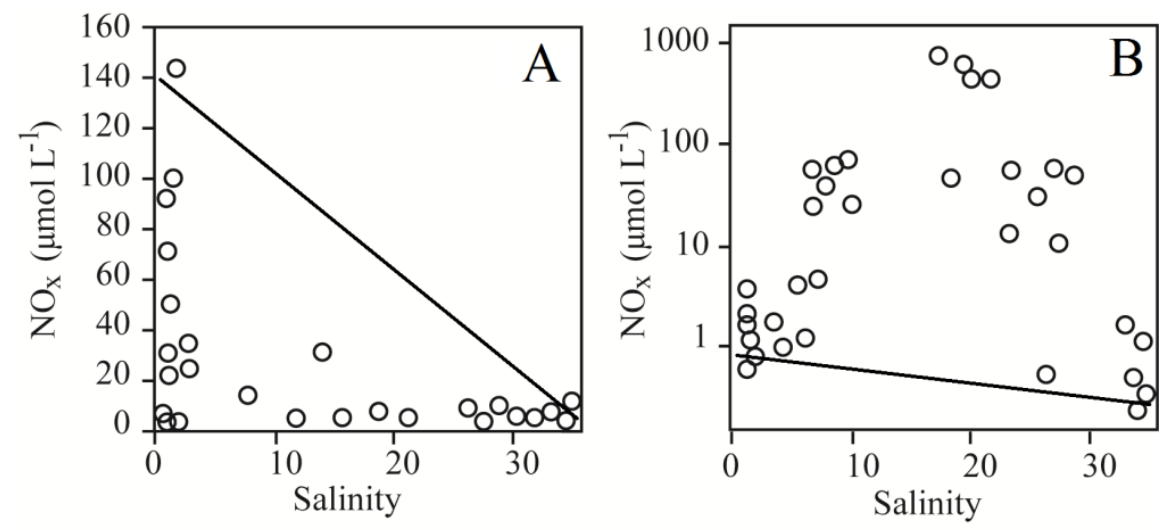

Figure 4. Examples of nitrate versus salinity scatter plots in (A) a nutrient-contaminated [Loveless and Oldham, 2010] and (B) an uncontaminated [Santos et al., 2009d] STE. The solid lines represent the theoretical conservative mixing line. In the contaminated CUA (A), nitrate was attenuated in the STE. In the uncontaminated CUA (B), nitrate was produced within the STE due to seawater inputs at high tide combined with mineralization within the STE. Notice the log scale on the ordinate axis in B.

It is important to quantify the source and travel pathways of nutrients through a CUA and STE in addition to the residence times and reaction rates. Recent research attempted to separate the relative contribution of FSGD versus saline SGD to nutrient and carbon fluxes. While FSGD represents a source of "new" water and dissolved species to the ocean, large quantities of marine organic matter can be mineralized in a STE, with saline SGD then delivering large quantities of metabolic products (e.g., phosphate, ammonium, nitrate, alkalinity, $\mathrm{CH}_{4}$, and $\mathrm{CO}_{2}$ ) to the ocean. Since the fresh and saline SGD components are usually superimposed, it is difficult to separate their relative contributions. In systems with high seawater productivity and organic matter content, saline SGD associated with tide- and wave-induced seawater circulating through the STE may release nutrients to the ocean due to the mineralization of marine organic matter [Anwar et al., 2014; Sadat-Noori et al., 2016b; Santos et al., 2009d]. The loads of marine 
organic matter delivered into a STE are lower where the coastal ocean is oligotrophic, which may result in FSGD rather than saline SGD dominating the nutrient fluxes to the ocean [Weinstein et al., 2011]. Quantifying SGD-derived nutrient fluxes to the ocean requires sitespecific understanding of biogeochemical transformations and groundwater flow processes in a STE. The typical approach for determining nutrient fluxes to the ocean is to multiply FSGD by nutrient concentrations in a CUA. This neglects transformations in the STE, consequently overestimating fluxes from contaminated CUAs (as in Figure 4A) and underestimating fluxes from CUAs where nitrate is produced (as in Figure 4B). An approach often used to bypass the assessment of biogeochemical transformations in the STE consists of sampling pore water in the seepage zone just before it discharges across the CUA-ocean interface [Santos et al., 2012a]. For this approach, the pore water concentrations in the seepage zone may be lower due to dilution of the terrestrial groundwater with large quantities of circulating seawater, and therefore consideration needs to be made for the high volume flux through the seepage zone. Defining reasonable endmembers for SGD remains a major challenge that often creates large uncertainties in site-specific investigations, especially when the physical drivers of SGD are poorly understood.

In spite of these uncertainties, different local and regional studies demonstrate that SGDassociated fluxes of nutrients into the coastal ocean can be comparable to or even higher than the relatively better quantified river fluxes [Slomp and Van Cappellen, 2004; Moore et al., 2008;

Santos et al., 2008]. Large scale estimates of SGD based on ${ }^{228} \mathrm{Ra}$ observations in large ocean basins are now available [Moore et al., 2008; Kwon et al., 2014]. However, there is little information on the related large-scale biogeochemical fluxes and their driving forces. Rodellas et al. [2015] quantified nutrient fluxes into the Mediterranean Sea and demonstrated that SGD may 
be comparable to river inputs of $\mathrm{N}, \mathrm{P}$ and silicon ( $\mathrm{Si}$ ) at the basin scale. Because total SGD fluxes were estimated from ${ }^{228}$ Ra measurements, saline SGD rather than FSGD is likely the main contributor to the estimated total SGD nutrient inputs to the Mediterranean Sea. Further, as groundwater endmember samples were collected in nearshore locations only, the SGD nutrient fluxes may be overestimated because most of the SGD may occur offshore where the recirculating seawater may be more nutrient poor than the nearshore groundwater.

Due to long groundwater travel times, it may take decades for nutrients to be transported through a CUA from their source to the ocean and therefore contamination of CUAs can represents a legacy pollution issue. While river-derived nutrient inputs into global estuaries tripled in the last few decades [Diaz and Rosenberg, 2008], nothing is known about similar changes in the SGD contribution. In areas with high groundwater nutrient loading, such as Florida and Chesapeake Bay, studies have shown nutrients are released to the ocean decades after the initial contamination of the CUA [Hu et al., 2006; Sanford and Pope, 2013]. In the Cook Islands, decade-old fresh groundwater from a shallow CUA is now discharging along the shoreline and degrading the adjacent coral reef lagoon [Tait et al., 2014].

Much of the STE and SGD literature focuses on nutrients. However, due to the role of oceans in the global carbon cycle and the rising threat of climate change and ocean acidification, the carbon cycle has been examined in recent coastal groundwater investigations, following pioneering papers that examined dissolved inorganic carbon (DIC) [Cai et al., 2003] and dissolved organic carbon (DOC) [Goni and Gardner, 2003]. For instance, Cai et al. [2003] observed high DIC levels in a STE that resulted in SGD-derived DIC fluxes 4-fold higher than regional river inputs into the coastal ocean. It is possible that STEs along coastlines with carbonate $\left(\mathrm{CaCO}_{3}\right)$ sediments may behave differently to STEs along quartz coastlines with 
respect to acting as a net source or sink of carbon [Cyronak et al., 2013]. However, little data are available on the biogeochemistry of carbonate sand STEs, although initial investigations indicate that SGD may release $\mathrm{CO}_{2}$ from respiration within carbonate sediments [Cyronak et al., 2014].

SGD may also modify the $\mathrm{pH}$ of the coastal ocean and locally influence ocean acidification [Santos et al., 2011b]. The ratios of DIC to carbonate alkalinity (Ac) in SGD provide insight into whether SGD acts as a buffer or driver of coastal acidification. DIC:Ac ratios $>1$ will result in SGD potentially decreasing seawater $\mathrm{pH}$, while DIC:Ac ratios <1 will result in SGD buffering seawater against ocean acidification. The extremely high $\mathrm{CO}_{2}$ often observed in coastal groundwater creates high DIC:Ac ratios, and thus a drop in receiving water $\mathrm{pH}$ in most sites investigated so far. This includes coastal wetlands [de Weys et al., 2011; Jeffrey et al., 2016], coral reef lagoons [Cyronak et al., 2014; Wang et al., 2014], an estuary [Sadat-Noori et al., 2016a] and a coastal embayment [Liu et al., 2017] (Figure 5). In Waquoit Bay, for example, seasonal investigations revealed that the SGD-derived DIC flux is always greater than Ac flux, indicating that SGD would reduce the $\mathrm{CO}_{2}$ buffering capacity of the coastal water [Liu et al., 2017]. However, seawater $\mathrm{pH}$ may also increase due to enhanced biological productivity supported by SGD-derived nutrients or by adsorption of protons on sediments [Lee and Kim, 2015]. Therefore, site-specific investigations are needed to determine how SGD may influence the $\mathrm{pH}$ of receiving waters.

The gases $\mathrm{CO}_{2}, \mathrm{~N}_{2} \mathrm{O}$, and $\mathrm{CH}_{4}$, which are the main anthropogenic greenhouse gases, are often enriched in CUAs [Addy et al., 2005; O'Reilly et al., 2015; Sadat-Noori et al., 2016a]. As such SGD may be an important greenhouse gas source. Early investigations used $\mathrm{CH}_{4}$ as a tracer of SGD [Bugna et al., 1996; Cable et al., 1996] and revealed significant correlations between $\mathrm{CH}_{4}$ and groundwater tracers such as ${ }^{222}$ Rnin coastal seawater [Dulaiova et al., 2006; Santos et al., 
2009a]. More recent work focused on how SGD can be a source of $\mathrm{CH}_{4}$ in a carbon budget context. This includes investigations in permafrost areas where SGD releases $\mathrm{CH}_{4}$ to the ocean [Lecher et al., 2016] and coral reef lagoons subject to significant tide-induced seawater recirculation through the nearshore aquifer [O'Reilly et al., 2015]. In these cases, tide-induced saline SGD rather than FSGD was suggested to be the main source of $\mathrm{CH}_{4}$ to the coastal ocean.

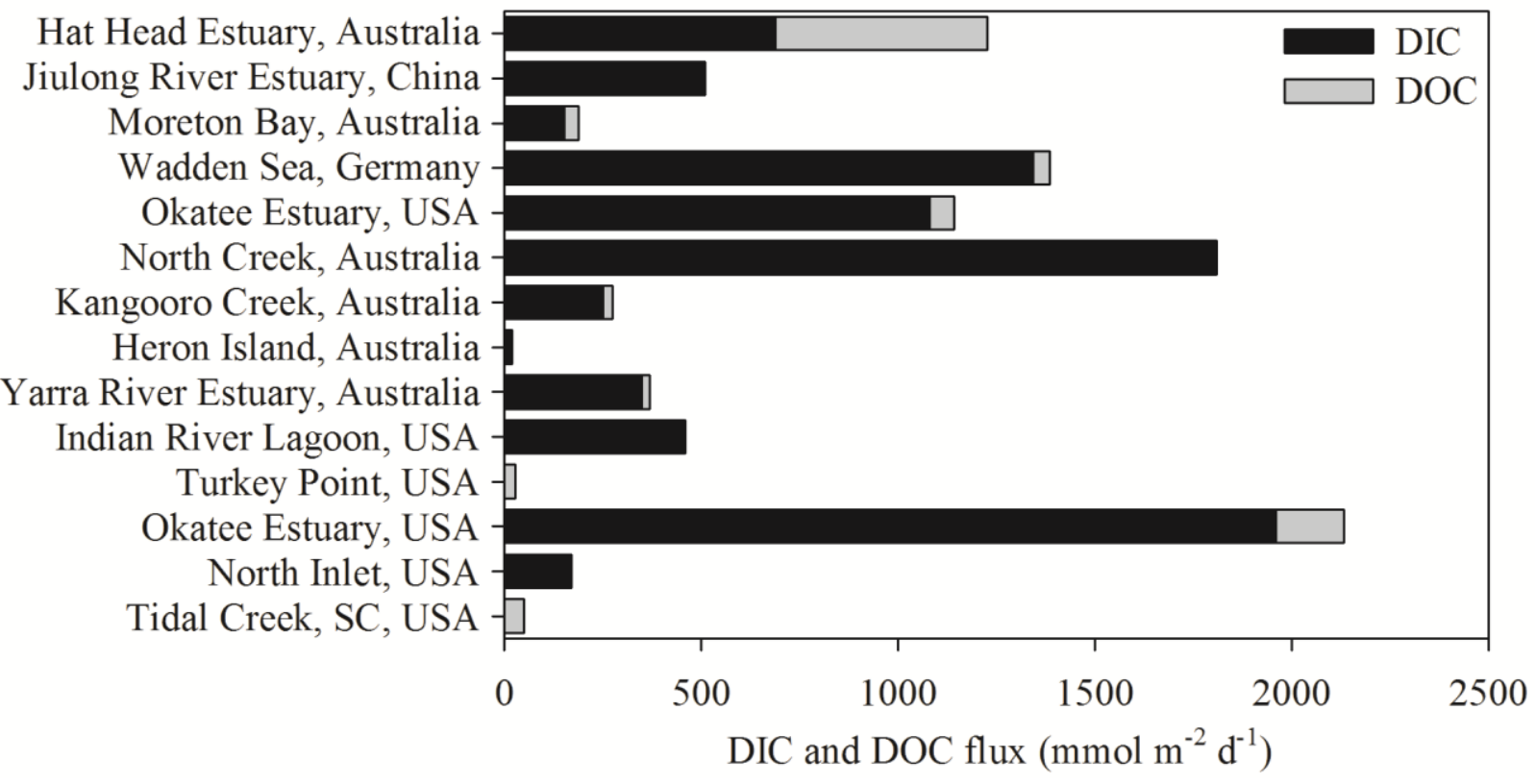

Figure 5. A compilation of SGD-derived dissolved inorganic (DIC) and dissolved organic carbon (DOC) fluxes. DIC fluxes on average were 13-fold greater than DOC fluxes in the seven systems where both species were measured. Original references and data can be found in Sadat-Noori et al. [2016a].

Even less is known about $\mathrm{N}_{2} \mathrm{O}$ production in STEs and associated SGD fluxes. $\mathrm{N}_{2} \mathrm{O}$ is formed as a byproduct during nitrification or as an intermediate product during denitrification. With field investigations [Kroeger and Charette, 2008; Santos et al., 2009d] and modelling [Spiteri et al., 
2008a] indicating that both denitrification and nitrification are important in STEs. SGD may be a two-fold source of $\mathrm{N}_{2} \mathrm{O}$ to surface waters. Initial investigations revealed significant fluxes of $\mathrm{N}_{2} \mathrm{O}$ associated with FSGD to an urban estuary [Wong et al., 2013] and in a coral reef lagoon where tides drive significant seawater recirculation through the aquifer [O'Reilly et al., 2015]. Additional work is needed to determine how SGD releases greenhouse gas to the coastal ocean, and whether SGD can explain supersaturated conditions often found in coastal waters.

\subsection{Metals}

The salinity gradient in a STE is often accompanied by redox changes [e.g., Beck et al., 2017], which can play a significant role in trace metal cycling. Trace metals with multiple oxidation states are particularly impacted by the redox gradients present in STEs. Iron $(\mathrm{Fe})$ and manganese (Mn) are among the most important metals due to their abundance in the earth's crust and therefore most aquifer solids. Further, the oxide form of these elements (i.e., Fe and Mn (hydr)oxides) are known to scavenge (through adsorption or co-precipitation) other elements, even those that do not have a redox chemistry of their own. Charette and Sholkovitz [2002] used the term "iron curtain" to describe the accumulation of Fe (hydr)oxides along the redox boundary of the STE. They found a significant correlation between Fe and P in aquifer sediments, and suggested that the iron curtain could act as a natural permeable reactive barrier for in situ removal of chemical species such as phosphate $\left(\mathrm{PO}_{4}-\mathrm{P}\right)$ that have a strong affinity for $\mathrm{Fe}$ (hydr)oxides. Later, Spiteri et al. [2006] used a reactive transport model to demonstrate that the iron curtain's formation is driven largely by $\mathrm{pH}$ (rather than redox) gradients, and that this process may be responsible for greatly reduced $\left(\mathrm{PO}_{4}-\mathrm{P}\right)$ transport to the coastal ocean via SGD. 
Iron curtain-like features have since been directly observed [Windom et al., 2006; Roy et al., 2010; Trezzi et al., 2016] or inferred [Beck et al., 2007; Santos et al., 2011b; Porubsky et al., 2014; O'Connor et al., 2015; Reckhardt et al., 2015] in numerous STEs worldwide. Some of these STEs include sulfide minerals [Beck et al., 2016]. The predominance of Fe-sulfides versus -oxides is likely determined by dissolved organic carbon (DOC) input to the STE and its residence time in the subsurface. However, there could be other contributing factors such as the microbial community and DOC residence time in the STE since some of the aforementioned STEs have high DOC concentrations yet the system never proceeds to sulfate $\left(\mathrm{SO}_{4}{ }^{2-}\right)$ reduction [e.g. Charette and Sholkovitz, 2002; Windom et al., 2006; Beck et al., 2007]. More work is required on this topic as solid-phase Fe speciation plays a key role in microbial biogeochemistry and trace metal cycling in aquatic environments including the STE. For example, Bone et al. [2006] found that amorphous forms of Fe (hydr)oxides were more efficient scavengers of arsenic (As) in the STE than the more crystalline forms.

It has been revealed that iron curtains are not static features - a decrease in aquifer recharge and terrestrial freshwater discharge through the STE can alter the lateral extent of the STE, thereby changing the area over which Fe (hydr)oxides can undergo reductive dissolution [Roy et al., 2013]. Further, seasonal and interannual variability in mean sea level can drive the DZ of the saltwater wedge (and its associated redox boundary, if present) in a landward or seaward direction. This seasonal movement was shown to correlate with dissolved $\mathrm{Fe}$ and $\mathrm{Mn}$ and also dissolved trace metals and nutrients that are known to associate with their (hydr)oxide form [Gonneea et al., 2013b; Gonneea and Charette, 2014]. In the northeastern United States, SLR between 1990-2007 was $\sim 0.5 \mathrm{~cm} \mathrm{y}^{-1}$ and has been accelerating in recent years [Sallenger et al., 2012]. In the case of Waquoit Bay, a $50 \mathrm{~cm}$ increase in sea level (conservative prediction for 
2100 ) is predicted to shift the saltwater wedge DZ $1 \mathrm{~m}$ vertically [Spiteri et al., 2008b]. The inventory of trace metals within that interval is substantial [Gonneea et al., 2013b]. Thus, on long time scales (years-decades), the DZ may advance landward in the STE, leading to additional fluxes of trace metals that are sensitive to increases in ionic strength or decreases in redox state. This process was also suggested for a mangrove STE in Brazil [Sanders et al., 2012].

Though most SGD studies have focused on the nutrient load delivered by groundwater to the coastal ocean, some have looked at metals delivered to the ocean via SGD. Trezzi et al. [2016] reported on SGD in a Mediterranean region where mine tailings had accumulated along the shoreline for several decades. They found that zinc $(\mathrm{Zn})$ and lead $(\mathrm{Pb})$ fluxes were significantly elevated in SGD relative to other locations worldwide [e.g., Beck et al., 2009]. Again, the mobilization of these metals in groundwater was attributed to the Fe and Mn redox cycles and the suspected low $\mathrm{pH}$ of the groundwater as it passed through the sediment deposits left behind from mining activities. Charette and Buesseler [2004] studied copper (Cu) fluxes in SGD near a naval base on the eastern coast of the United States, but found that this source was minor compared to that from Cu-based antifouling paints used on boat hulls. Beck et al. [2009] compared SGD-derived metal inputs to those from treated wastewater inputs to a surface estuary near New York City. They were able to use stable $\mathrm{Pb}$ isotopes to differentiate groundwater versus sewage-derived $\mathrm{Pb}$ inputs, and also to determine the $\mathrm{Pb}$ source. Although trace metal concentrations were generally higher in the treated wastewater compared to metal concentrations in the STE, the SGD trace metal source was equally as important due to the higher magnitude of SGD.

Aside from Fe and Mn, mercury $(\mathrm{Hg})$ has arguably been the most studied trace metal in STEs and SGD due to its potential impact on human health through consumption of pelagic fish, which 
are bio-accumulators of $\mathrm{Hg}$ in aquatic environments. Bone et al. [2007] reported $\mathrm{Hg}$ enrichment in an STE, which they attributed to a combination of high $\mathrm{Hg}$ in recharge to the CUA combined with low organic carbon content in aquifer solids that might otherwise increase the solid-aqueous phase partitioning for Hg. This resulted in SGD inputs to a local embayment that exceeded the area-normalized atmospheric deposition rate for the northeastern United States. This is similar to findings for a Korean embayment that exchanges with the Yellow Sea [Rahman et al., 2013]. Evidence exists for iron curtain control on groundwater Hg cycling; Johannesson and Neumann [2013] observed dissolved Hg release during reductive dissolution of Fe (hydr)oxides in a deep confined aquifer. In contrast, Szymczycha et al. [2013] reported non-conservative removal (loss) of dissolved Hg during saltwater-freshwater mixing in a STE at their study site (southern Baltic Sea), SGD was a minor source compared to rivers and atmospheric deposition. Laurier et al. [2007] found that mussels from beds located within a zone of enhanced SGD had significantly higher $\mathrm{Hg}$ in their tissues compared with those harvested from non-SGD impacted locations. Black et al. [2009] found that monomethyl-Hg (MMHg) fluxes from SGD were similar to those from fine grained surface sediments of a coastal Californian embayment; Lee et al. [2011] reported a similar result for a Korean volcanic island. These examples are noteworthy because MMHg is the major Hg-species that is known to bio-accumulate through the food web and can lead to dangerous levels of $\mathrm{Hg}$ in fish that are harvested for human consumption. SGD-driven salinity changes played a role in partitioning of $\mathrm{Hg}$ from solid phases to the dissolved (and presumably more bio-available) phase in the surf zone of Californian and Hawaiian beaches [Ganguli et al., 2012; Ganguli et al., 2014]. Ganguli et al. [2012] also showed the importance of tides in controlling temporal variability in $\mathrm{Hg}$ flux to the ocean with a 5-fold increase in seawater MMHg (from 0.1 to $0.5 \mathrm{pM}$ ) at low tide compared to high tide due to the higher SGD rate. It can 
be inferred that the source of this increase is from production in shallow (cm-scale) sediments of the STE, as the DZ of the saltwater wedge does not appear to respond to short-term changes in sea level such as those due to tides [Gonneea et al., 2013a].

These examples illustrate the progress that has been made in our understanding of local-scale impacts of SGD on coastal ocean trace metal budgets. However, the role of SGD on metal inputs to oceans on regional to global scales remains unclear. A study by Windom et al. [2006] on Fe fluxes from the South American continent suggests that SGD is on par with atmospheric Fe delivery to the entire South Atlantic Ocean. Beck et al. [2013] used a coastal typology approach to derive the strontium ( $\mathrm{Sr}$ ) and $\mathrm{Sr}$ isotope budget for the global ocean that included SGD. Such an approach might be used to scale local SGD process studies to global input rates for contaminant type trace metals.

Seasonality is also known to play an important role in SGD-derived trace metal fluxes to the coastal ocean. Jeong et al. [2012] found that trace metal fluxes from the coastal aquifer of a volcanic Korean island were about 20 -fold higher in summer compared to winter, driven not by changes in SGD, but rather by higher summertime groundwater trace metal concentrations. They speculated that the differences were driven by much higher DOC inputs of marine origin to the STE during summer, and the higher rates of redox cycling that would come with microbial processing of the DOC. These results are consistent with another study that found that seasonality in STE metal concentration, not water flux, was the main driver for changes in the magnitude of metal fluxes to surface waters carried by SGD [Gonneea et al., 2013a]. These findings are important because it is often assumed that SGD-derived chemical fluxes are in phase with rates of SGD [e.g., Kelly and Moran, 2002; Moore and Shaw, 2008]. Hence, the timing of 
trace metal fluxes as well as other chemicals to the coastal ocean may not coincide with patterns in the annual water cycle.

In some coastal ocean trace metal budgets, SGD can be a net sink via removal of trace metals as seawater recirculates across the CUA-ocean interface and through the STE. Uranium (U) is a trace metal with two main redox states in aquatic systems, one that is mobile in oxic waters and another that is particle reactive under reducing conditions. Hence, the reducing environment of the STE appears to make it a net sink for U [Charette and Sholkovitz, 2006; Santos et al., 2011a], which is present in seawater at ppb concentrations. Santos et al. [2011a], using rapid (90 min) sampling of a STE over a $16 \mathrm{~h}$ period, provided evidence that tide-induced water exchange was a control on $\mathrm{U}$ removal (and release in the case of Ba). Beck et al. [2009] found that $\mathrm{Cu}$ was removed within the STE of a coastal New York embayment, though they did not comment on the potential driving mechanism for this process. Regardless, the time-scale over which these conditions that are a removal will determine whether or not STEs are important for trace metal removal on longer (e.g., decadal to centennial and beyond) time scales [Beck et al., 2010]. Supporting long-term trace metal removal within STEs, Jung et al. [2009] calculated that the As accumulation by the iron curtain at Waquoit Bay took place over $2000 \mathrm{y}$.

\subsection{Organic Contaminants}

With many urban areas, industrial sites, refineries and transport hubs (airports, harbors) located along coastlines, elevated concentrations of organic contaminants (e.g., hydrocarbons (petroleum products), chlorinated solvents, polyaromatic hydrocarbons and pesticides) in CUAs are common in developed areas [Zhao et al., 2011; Sbarbati et al., 2015]. Where terrestrial groundwater discharges to the ocean and organic contamination of the CUA is near the shoreline (i.e., $<1$ 
$\mathrm{km}$ ), there is potential for the contaminants to migrate to the coastal ocean via FSGD [Westbrook et al., 2005; Mastrocicco et al., 2012; Colombani et al., 2014].

Few studies have investigated the potential migration of organic contaminants through CUAs to the ocean including the potential natural attenuation of contaminants along redox and $\mathrm{pH}$ gradients in the STE. A field investigation of a dissolved hydrocarbon groundwater plume (BTEXN; benzene, toluene, ethylbenzene and xylenes, naphthalene) flowing towards a tidal and seasonally-influenced surface water estuary was presented by Westbrook et al. [2005]. They demonstrated that tidal effects including tide-induced recirculation strongly influenced the distribution of the hydrocarbon compounds near the shore and their spatial and temporal discharge to the estuary. Robinson et al. [2009] numerically simulated the transport of a BTEX groundwater plume in a tidally-influenced STE, considering Monod kinetics to describe the biodegradation of BTEX species. They showed that the redox gradients in the STE enhanced biodegradation of the BTEX species and subsequently reduced contaminant fluxes to the coastal ocean. The magnitude of FSGD to the tidal force (i.e., tidal amplitude) was found to considerably alter the extent of biodegradation as it affects the extent of mixing in the STE and period of exposure of the BTEX species to oxygen in the mixing zone. Further, this ratio controls tide-induced recirculation rate and thus the rate of oxygen and organic matter delivery from the ocean to the STE. Even neglecting reactions, both tide and wave-induced circulations and associated saltwater-freshwater mixing can considerably reduce organic contaminant concentrations at the seabed via dilution [Robinson et al., 2007b; Robinson et al., 2009; Geng et al., 2014].

Most organic contaminants enter the subsurface as NAPLs (non-aqueous phase liquids) with dissolved contaminant plumes forming as the NAPL partitions into the aqueous phase. No 
studies have examined the effects of coastal groundwater dynamics on the morphology and migration of NAPLs in CUAs although reversing hydraulic gradients and fluctuating watertables may modify NAPL transport, entrapment, and mass transfer between the NAPL and aqueous phases. Numerical modeling and laboratory studies have, however, evaluated the effect of tides and waves on dense aqueous contaminant plumes showing strong interactions between tideinduced circulations and dense contaminant plumes as well as the potential occurrence of flow instabilities [Zhang et al., 2002; Brovelli et al., 2007; Bakhtyar et al., 2013; Liu et al., 2016].

Organic contaminants can also be delivered to a nearshore aquifer from the ocean, for instance, following an offshore oil spill. Contamination of beaches from oil spills can severely degrade nearshore ecosystems [National Research Council, 2013]. Oil can be transported by wave and tide-induced circulations into the beach sediments where it can be attenuated by natural biodegradation. Physical remediation efforts (e.g., manual scrubbing, pressure spraying) are also often able to remove large amounts of oil from shallow beach sediment [Owens et al., 2008]. However, in some cases oil has been found to infiltrate and persist in beach sediments for decades after an offshore spill [Owens et al., 2008; Li and Boufadel, 2010]. This tends to occur at beaches where there is a high permeability upper layer (i.e., gravel) that is underlain by a low permeability layer. The upper layer is able to temporarily store the oil until it penetrates into the lower layer where it becomes entrapped by capillary forces and biodegradation is limited due to the reducing conditions in the low permeability sediment [Boufadel et al., 2010; Li and Boufadel, 2010]. In this way, oil is able to persist in the beach sediment until there is a change in environmental conditions (e.g., storm event) that leads to erosion of the shoreline [Owens et al., 2008]. Recent numerical simulations by Geng et al. [2015] and Geng et al. [2016b] illustrated the important role of tide-induced circulations, nearshore groundwater flows and chemistry in the 
shallow nearshore aquifer (i.e., availability of nutrients and dissolved oxygen) in controlling the aerobic biodegradation of residual oil in tidally-influenced beaches. They showed that biodegradation in the intertidal zone can be either oxygen- or nutrient-limited, and varies along across the intertidal zone based on the varying inputs of the seawater and fresh groundwater endmembers. Simulating the downward migration and morphology of NAPL (oil) in beaches exposed to wave and tidal forcing is challenging. For instance, multiphase simulations presented by Malott et al. [2017] demonstrated that instantaneous wave- and tide-induced pressure signals need to be considered in predicting NAPL infiltration into beach sediments. Therefore, simplified modeling approaches that consider only tide- and wave time-averaged flow fields may not be adopted. With offshore oil spills a continuing threat to coastal nearshore ecosystems, it is important that research continues on the processes controlling the migration, morphology and longevity of oil in nearshore aquifers.

\section{Knowledge gaps and research needs}

Despite considerable research effort focused on understanding interactions between CUAs and the coastal ocean in the last $20 \mathrm{y}$, major knowledge gaps remain regarding this connection between the land and ocean that can considerably influence on the integrity of the coastal ocean, availability of fresh groundwater resources, and marine biogeochemical cycles. Based on the review provided, the following knowledge gaps and research needs were identified:

- The driving forces for flows and salt transport in a STE are highly dynamic and irregular with multiple forces acting on the system. Most field and numerical modelling studies evaluate the effect of individual driving forces on groundwater flow and salt transport in a STE in isolation or consider two forces only (e.g., tides and seasonal recharge). While this 
has provided strong mechanistic understanding of the forcing effects, there is a need to better understand the interacting effects between forcing including the non-linearity of the interactions and how they interact to control nearshore groundwater dynamics and chemical fluxes. Further, approaches need to be developed to better identify settings where one forcing or a couple of forcing may dominate over others. For instance, as shown by Xin et al. [2014], approaches such as functional data analysis may be applied to quantify the effects of multiple irregular forcing on SGD taking into account the historical forcing conditions and memory effects.

- Significantly more research effort to date has been devoted to the effect of density and semidiurnal/diurnal tides on the flows, salt transport and geochemical processes within a STE compared to more irregular and longer period forcing such as waves, seasonal recharge, sea level variability, and sea level rise. This is likely in part due to the challenges inherent in investigating irregular and longer period forcing via field experiments as well as the difficulties of disentangling the various forcing effects. Irregular forcing, particularly varying wave conditions and episodic events such as overland seawater inundation, may have a great impact on the salinity distribution, mixing and geochemical processes within a CUA due to potential large-scale salinization combined with the slow recovery (freshening) of the aquifer [Smith et al., 2008; Robinson et al., 2014; Yu et al., 2016]. Large-scale salinization of a CUA may also, for instance, lead to mobilization of legacy metals and organic contaminants, although these potential impacts have not been explored. Increased knowledge of the effects of irregular and longer period forcing is needed to better predict perturbations in the system in response to the changing climate and increasing anthropogenic stressors. 
- Most studies examining chemical transformations in a STE and fluxes to the coastal sea (metals, nutrients, carbon, greenhouse gases) are field-based with limited measurements and understanding of the underlying physical processes (e.g., water exchange, groundwater circulations) and often give limited consideration to the coupling of biogeochemical cycles (i.e., nitrogen, carbon, metal cycling). The physical processes need to be studied and measured together with the coupled biogeochemical processes as the interactions between these processes holds the key to unravelling questions regarding the role of the STE in controlling chemical fluxes to the ocean. There is also a need to combine field measurements with reactive transport models, which are currently underutilized in STE studies, to generate broadly applicable mechanistic understanding including clarification of the interactions between flows, residence times and kinetics. Combining physical and geochemical investigations, and field and modeling efforts is challenging as researchers generally tend to have more expertise in one area only (i.e., hydrology or geochemistry) - multi-disciplinary teams may be required to address this.

- The salt and geochemical conditions in a STE depend on the current as well as historic forcing conditions due to the slow recovery time of the system to transient forces. A natural CUA system is rarely in equilibrium as it is continuously adjusting to the effects of previous conditions. This includes adjusting to both physical forcing conditions as well as changes in end member chemical concentrations over time. Despite this, many field studies continue to obtain only snapshot (one-off) distributions of the salt and chemical distributions in a STE, thus they do not determine the effects of historical conditions. This may lead to misinterpretation of field data including drawing incorrect conclusions regarding the effect of different forces and chemical behavior. For instance, temporal changes in endmember 
concentrations may lead to mixing patterns being interpreted as non-conservative mixing, but rather the patterns reflect conservative mixing among multiple endmembers that vary temporally. Collection of field data over long durations to ensure the effects of past conditions is understood is highly intensive. Therefore, there is a need for better fundamental understanding of the temporal effects such that they can be incorporated into field investigations and data interpretation.

- Coastlines and thus nearshore aquifer systems are three-dimensional due to shoreline features such as creeks and rocky outcrops, and varying alongshore morphology and subsurface geological heterogeneities. Most field and numerical modelling studies assume that the system is $2 \mathrm{D}$ with negligible alongshore and geological variability. This simplification allows for the use of a single cross-shore transect for field monitoring and use of a $2 \mathrm{D}$ numerical model with unit alongshore width. While this simplification is valuable for developing process-based understanding of the physical and biogeochemical processes in CUAs, there is a need to expand investigations to consider the heterogeneous nature of the system. As illustrated by Zhang et al. [2016] and Russoniello et al. [2013], alongshore variability and aquifer heterogeneities may play a key role in controlling SGD and the physical and biogeochemical processes in a STE. Further, most studies assume that the beach morphology (cross-shore and alongshore) is constant, neglecting erosional and accretionary beach processes. The changes in the morphology of the beach face will affect the water exchange leading to shifts in groundwater circulation patterns and may enhance saltwater-freshwater mixing in a STE. While this has been investigated in a few studies [Robinson et al., 2006; Abarca et al., 2013], beach morphology changes may have important implications on the 
biogeochemistry and transformations in a STE and requires further investigation as we seek to understand fully the transient behavior of this complex system.

- While regional and global scale estimates of the magnitude and importance of SGD are available [e.g., Zektser and Loaiciga, 1993; Moore et al., 2008; Sawyer et al., 2016], improved quantification of the role of the STE and SGD in controlling nutrient, carbon, greenhouse gas and metal fluxes to the coastal ocean on global and ocean basin scales is needed. There have been limited attempts on measuring these fluxes over large scales other than Rodellas et al. [2015] who provided estimates of nutrients fluxes into the Mediterranean Sea. There is a need to upscale local scale investigations based on broadly applicable understanding of controlling factors.

- Much of the earlier SGD literature was based on bottom-up approaches, e.g., SGD fluxes are estimated and compared to other sources such as river inputs [see Slomp and Van Cappellen, 2004 for a review]. Bottom-up studies alone do not demonstrate whether the estimated SGD flux results in a measurable impact on the coastal ocean because of inherent challenges to define the spatial and temporal scale of both river and groundwater inputs. In recent years, top-down evidence (i.e., a demonstrated cause-effect) has emerged illustrating clearer links between groundwater inputs and a biogeochemical response in coastal waters. For example, groundwater inputs have been linked to high $\mathrm{N}: \mathrm{P}$ ratios in estuarine waters [Santos et al., 2013], high microphytobenthos production in intertidal flats [Waska and Kim, 2010], and algal blooms in coastal waters [Lee et al., 2010]. To obtain stronger evidence on the importance of SGD to marine budgets, investigations need to combine both bottom-up and top-down approaches. 


\section{Acknowledgements}

This work was partially supported by 111 Project approved by the Ministry of Education and the State Administration of Foreign Experts Affairs. The authors acknowledge valuable comments from editor, and two anonymous reviewers, which significantly improved paper. 


\section{References}

Abarca, E., Karam, H., Hemond, H.F., Harvey, C.F., 2013. Transient groundwater dynamics in a coastal aquifer: The effects of tides, the lunar cycle, and the beach profile, Water Resour. Res., 49 (5), 2473-2488, http://dx.doi.org/10.1002/wrcr.20075.

Addy, K., Gold, A., Nowicki, B., McKenna, J., Stolt, M., Groffman, P., 2005. Denitrification capacity in a subterranean estuary below Rhode Island fringing salt marsh, Estuaries, 28 (6), 896-908, http://dx.doi.org/10.1007/BF02696018.

Alongi, D.M., Sasekumar, A., Chong, V.C., Pfitzner, J., Trott, L.A., Tirendi, F., Dixon, P., Brunskill, G.J., 2004. Sediment accumulation and organic material flux in a managed mangrove ecosystem: estimates of land-ocean-atmosphere exchange in peninsular Malaysia, Mar. Geol., 208 (2-4), 383-402, http://dx.doi.org/10.1016/j.margeo.2004.04.016.

Alongi, D.M., 2008. Mangrove forests: Resilience, protection from tsunamis, and responses to global climate change, Estuar. Coast. Shelf Sci., 76 (1), 1-13, http://dx.doi.org/10.1016/j.ecss.2007.08.024.

Anderson, W.P., Lauer, R.M., 2008. The role of overwash in the evolution of mixing zone morphology within barrier islands, Hydrogeol. J., 16, 1483-1495, http://dx.doi.org/10.1007/s10040-008-0340-z.

Anderson, W.P., Emanuel, R.E., 2010. Effect of interannual climate oscillations on rates of submarine groundwater discharge, Water Resour. Res., 46 (5), W05503, http://dx.doi.org/10.1029/2009WR008212. 
Anschutz, P., Smith, T., Mouret, A., Deborde, J., Bujan, S., Poirier, D., Lecroart, P., 2009. Tidal sands as biogeochemical reactors, Estuar. Coast. Shelf Sci., 84 (1), 84-90, http://dx.doi.org/10.1016/j.ecss.2009.06.015.

Anwar, N., Robinson, C., Barry, D.A., 2014. Influence of tides and waves on the fate of nutrients in a nearshore aquifer: Numerical simulations, Adv. Water Resour., 73, 203-213, http://dx.doi.org/10.1016/j.advwatres.2014.08.015.

Ataie-Ashtiani, B., Volker, R.E., Lockington, D.A., 1999. Tidal effects on sea water intrusion in unconfined aquifers, J. Hydrol., 216 (1-2), 17-31, http://doi.org/10.1016/S0022-1694(98)002753.

Back, W., Hanshaw, B.B., Pyle, T.E., Plummer, L.N., Weidie, A.E., 1979. Geochemical significance of groundwater discharge and carbonate solution to the formation of Caleta Xel Ha, Quintana Roo, Mexico, Water Resour. Res., 15 (6), 1521-1535, http://dx.doi.org/10.1029/WR015i006p01521.

Bakhtyar, R., Brovelli, A., Barry, D.A., Li, L., 2011. Wave-induced water table fluctuations, sediment transport and beach profile change: Modeling and comparison with large-scale laboratory experiments Coast. Eng., 58 (1), 103-118, http://doi.org/10.1016/j.coastaleng.2010.08.004.

Bakhtyar, R., Barry, D.A., Brovelli, A., 2012. Numerical experiments on interactions between wave motion and variable-density coastal aquifers, Coast. Eng., 60 (1), 95-108, http://dx.doi.org/10.1016/j.coastaleng.2011.09.001. 
Bakhtyar, R., Brovelli, A., Barry, D.A., Robinson, C., Li, L., 2013. Transport of variable-density solute plumes in beach aquifers in response to oceanic forcing, Adv. Water Resour., 53, 208-224, http://doi.org10.1016/j.advwatres.2012.11.009.

Baldock, T.E., Baird, A.J., Horn, D.P., Mason, T., 2001. Measurements and modeling of swashinduced pressure gradients in the surface layers of a sand beach, J. Geophys. Res.: Oceans, 106 (C2), 2653-2666, http://dx.doi.org/10.1029/1999JC000170.

Bange, H.W., 2006. Nitrous oxide and methane in European coastal waters, Estuar. Coast. Shelf Sci., 70 (3), 361-374, http://doi.org/10.1016/j.ecss.2006.05.042.

Beck, A.J., Tsukamoto, Y., Tovar-Sanchez, A., Huerta-Diaz, M., Bokuniewicz, H.J., SanudoWilhelmy, S.A., 2007. Importance of geochemical transformations in determining submarine groundwater discharge-derived trace metal and nutrient fluxes, Appl. Geochem., 22 (2), 477-490, http://dx.doi.org/10.1016/j.apgeochem.2006.10.005.

Beck, A.J., Cochran, J.K., Sañudo-Wilhelmy, S.A., 2009. Temporal trends of dissolved trace metals in Jamaica Bay, NY: Importance of wastewater input and submarine groundwater discharge in an urban estuary, Estuar. Coasts, 32 (3), 535-550, http://dx.doi.org/10.1007/s12237009-9140-5.

Beck, A.J., Cochran, J.K., Sanudo-Wilhelmy, S.A., 2010. The distribution and speciation of dissolved trace metals in a shallow subterranean estuary, Mar. Chem., 121 (1-4), 145-156, http://dx.doi.org/10.1016/j.marchem.2010.04.003. 
Beck, A.J., Charette, M.A., Cochran, J.K., Gonneea, M.E., Peucker-Ehrenbrink, B., 2013.

Dissolved strontium in the subterranean estuary - Implications for the marine strontium isotope budget, Geochem. Cosmochim. Acta, 117, 33-52, http://dx.doi.org/10.1016/j.gca.2013.03.021.

Beck, A.J., Kellum, A.A., Luek, J.L., Cochran, M.A., 2016. Chemical flux associated with spatially and temporally variable submarine groundwater discharge, and chemical modification in the subterranean estuary at Gloucester Point, VA (USA), Estuar. Coasts, 39 (1), 1-12, http://dx.doi.org/10.1007/s12237-015-9972-0.

Beck, M., Reckhardt, A., Amelsberg, J., Bartholomä, A., Brumsack, H.-J., Cypionka, H., Dittmar, T., Engelen, B., Greskowiak, J., Hillebrand, H., Holtappels, M., Neuholz, R., Köster, J., Kuypers, M.M.M., Massmann, G., Meier, D., Niggemann, J., Paffrath, R., Pahnke, K., Rovo, S., Striebel, M., Vandieken, V., Wehrmann, A., Zielinski, O., 2017. The drivers of biogeochemistry in beach ecosystems: A cross-shore transect from the dunes to the low-water line, Mar. Chem., 190, 35-50, http://dx.doi.org/10.1016/j.marchem.2017.01.001.

Black, F.J., Paytan, A., Knee, K.L., De Sieyes, N.R., Ganguli, P.M., Gray, E., Flegal, R., 2009. Submarine groundwater discharge of total mercury and monomethylmercury to central California coastal waters, Environ. Sci. Technol., 43 (15), 5652-5659, http://dx.doi.org/10.1021/es900539c.

Bokuniewicz, H., Buddemeier, R., Maxwell, B., Smith, C., 2003. The typological approach to submarine groundwater discharge (SGD), Biogeochemistry, 66 (1-2), 145-158, http://dx.doi.org/10.1023/B:BIOG.0000006125.10467.75. 
Bone, S.E., Gonneea, M.E., Charette, M.A., 2006. Geochemical cycling of arsenic in a coastal aquifer, Environ. Sci. Technol., 40 (10), 3273-3278, http://dx.doi.org/10.1021/es052352h.

Bone, S.E., Charette, M.A., Lamborg, C.H., Gonneea, M.E., 2007. Has submarine groundwater discharge been overlooked as a source of mercury to coastal waters? Environ. Sci. Technol., 41 (9), 3090-3095, http://dx.doi.org/10.1021/es0622453.

Borja, Á., 2005. The European Water Framework Directive: A challenge for nearshore, coastal and continental shelf research, Cont. Shelf Res., 25 (14), 1768-1783, http://dx.doi.org/10.1016/j.csr.2005.05.004.

Bosello, F., Roson, R., Tol, R.S.J., 2007. Economy-wide estimates of the implications of climate change: sea level rise, Environ. Resour. Econ., 37 (3), 549-571, http://dx.doi.org/10.1007/s10640-006-9048-5.

Boufadel, M.C., 2000. A mechanistic study of nonlinear solute transport in a groundwatersurface water system under steady state and transient hydraulic conditions, Water Resour. Res., 36 (9), 2549-2565, http://dx.doi.org/10.1029/2000WR900159.

Boufadel, M.C., T, S.M., Venosa, A.D., 2006. Tracer studies in laboratory beach simulating tidal influences, J. Environ. Eng., 132 (6), 616-623, http://dx.doi.org/10.1061/(ASCE)07339372(2006)132:6(616)

Boufadel, M.C., Li, H., Duidan, M.T., Venosa, A.D., 2007. Tracer studies in a laboratory beach subjected to waves, J. Environ. Eng., 133 (7), 722-732. 
Boufadel, M.C., Xia, Y., Li, H., 2011. Modeling solute transport and transient seepage in a laboratory beach under tidal influence, Environ. Model. Softw., 26 (7), 899-912, http://dx.doi.org/10.1016/j.envsoft.2011.02.005.

Brovelli, A., Mao, X., Barry, D.A., 2007. Numerical modeling of tidal influence on densitydependent contaminant transport, Water Resour. Res., 43 (10), W10426, http://dx.doi.org/10.1029/2006WR005173.

Brutsaert, W. (2005), Hydrology: An Introduction, Cambridge University Press.

Bugna, G.C., Chanton, J.P., Cable, J.E., Burnett, W.C., Cable, P.H., 1996. The importance of groundwater discharge to the methane budgets of nearshore and continental shelf waters of the northeastern Gulf of Mexico, Geochem. Cosmochim. Acta, 60 (23), 4735-4746, http://doi.org/10.1016/S0016-7037(96)00290-6.

Buquet, D., Sirieix, C., Anschutz, P., Malaurent, P., Charbonnier, C., Naessens, F., Bujan, S., Lecroart, P., 2016. Shape of the shallow aquifer at the fresh water-sea water interface on a highenergy sandy beach, Estuar. Coast. Shelf Sci., 179, 79-89, http://dx.doi.org/10.1016/j.ecss.2015.08.019.

Burnett, W.C., Taniguchi, M., Oberdorfer, J., 2001. Measurement and significance of the direct discharge of groundwater into the coastal zone, J. Sea Res., 46 (2), 109-116, http://doi.org/10.1016/S1385-1101(01)00075-2.

Burnett, W.C., Bokuniewicz, H., Huettel, M., Moore, W.S., Taniguchi, M., 2003. Groundwater inputs to the coastal zone, Biogeochemistry, 66 (1-2), 3-33, http://dx.doi.org/10.1023/B:BIOG.0000006066.21240.53. 
Burnett, W.C., Aggarwal, P.K., Aureli, A., Bokuniewicz, H., Cable, J.E., Charette, M.A., Kontar, E., Krupa, S., Kulkarni, K.M., Loveless, A., Moore, W.S., Oberdorfer, J.A., Oliveira, J., Ozyurt, N., Povinec, P., Privitera, A.M.G., Rajar, R., Ramessur, R.T., Scholten, J., Stieglitz, T., Taniguchi, M., Turner, J.V., 2006. Quantifying submarine groundwater discharge in the coastal zone via multiple methods, Sci. Total. Environ., 367 (2-3), 498-543, http://dx.doi.org/10.1016/j.scitotenv.2006.05.009.

Cable, J.E., Bugna, G.C., Burnett, W., Chanton, J.P., 1996. Application of ${ }^{222} \mathrm{Rn}$ and $\mathrm{CH}_{4}$ for assessment of groundwater discharge to the coastal ocean, Limnol. Oceanogr., 41 (6), 13471353, http://dx.doi.org/10.4319/1o.1996.41.6.1347.

Cai, W.J., Wang, Y., Krest, J., Moore, W.S., 2003. The geochemistry of dissolved inorganic carbon in a surficial groundwater aquifer in North Inlet, South Carolina, and the carbon fluxes to the coastal ocean, Geochem. Cosmochim. Acta, 67 (4), 631-639, http://doi.org/10.1016/S00167037(02)01167-5.

Carabin, G., Dassargues, A., 1999. Modeling groundwater with ocean and river interaction, Water Resour. Res., 35 (8), 2347-2358, http://dx.doi.org/10.1029/1999WR900127.

Charbonnier, C., Anschut, P., Poirier, D., Bujan, S., Lecroart, P., 2013. Aerobic respiration in a high-energy sandy beach, Mar. Chem., 155, 10-21, http://dx.doi.org/10.1016/j.marchem.2013.05.003.

Charette, M.A., Sholkovitz, E.R., 2002. Oxidative precipitation of groundwater-derived ferrous iron in the subterranean estuary of a coastal bay, Geophys. Res. Lett., 29 (10), 85-1 - 85-4, http://dx.doi.org/10.1029/2001GL014512. 
Charette, M.A., Buesseler, K.O., 2004. Submarine groundwater discharge of nutrients and copper to an urban subestuary of Chesapeake Bay (Elizabeth River), Limnol. Oceanogr., 49 (2), 376-385, http://dx.doi.org/10.4319/1o.2004.49.2.0376.

Charette, M.A., Sholkovitz, E.R., 2006. Trace element cycling in a subterranean estuary: Part 2. Geochemistry of the pore water, Geochem. Cosmochim. Acta, 70 (4), 811-826, http://dx.doi.org/10.1016/j.gca.2005.10.019.

Charette, M.A., 2007. Hydrologic forcing of submarine groundwater discharge: Insight from a seasonal study of radium isotopes in a groundwater-dominated salt marsh estuary, Limnol. Oceanogr., 52 (1), 230-239, http://dx.doi.org/10.4319/1o.2007.52.1.0230.

Chen, B.F., Hsu, S.M., 2004. Numerical study of the tidal effects on seawater intrusion in confined and unconfined aquifers by time independent finite difference method, J. Waterway Port Coast. Ocean Eng., 130 (4), 191-206, http://dx.doi.org/10.1061/(ASCE)0733950X(2004)130:4(191).

Cho, H.-M., Kim, G., 2016. Determining groundwater Ra end-member values for the estimation of the magnitude of submarine groundwater discharge using Ra isotope tracers, Geophys. Res. Lett., 43 (8), 3865-3871, http://dx.doi.org/10.1002/2016GL068805.

Colombani, N., Pantano, A., Mastrocicco, M., Petitta, M., 2014. Reactive modelling of 1,2-DCA and DOC near the shoreline, J. Contam. Hydrol., 169 (Supplement C), 100-111, https://doi.org/10.1016/j.jconhyd.2014.08.003. 
Cooper, H.H., 1959. A hypothesis concerning the dynamic balance of fresh water and salt water in a coastal aquifer, J. Geophy. Res., 64 (4), 461-467, http://dx.doi.org/10.1029/JZ064i004p00461.

Cyronak, T., Santos, I.R., Erler, D.V., Eyre, B.D., 2013. Groundwater and porewater as major sources of alkalinity to a fringing coral reef lagoon (Muri Lagoon, Cook Islands), Biogeosciences, 10 (4), 2467-2480, http://doi.org/10.5194/bg-10-2467-2013.

Cyronak, T., Santos, I.R., Erler, D.V., Maher, D.T., Eyre, B.D., 2014. Drivers of $p \mathrm{CO}_{2}$ variability in two contrasting coral reef lagoons: The influence of submarine groundwater discharge, Global Biogeochem. Cycles, 28 (4), 398-414, http://dx.doi.org/10.1002/2013gb004598.

Day, J.W., Christian, R.R., Boesch, D.M., Yáñez-Arancibia, A., Morris, J., Twilley, R.R., Naylor, L., Schaffner, L., Stevenson, C., 2008. Consequences of climate change on the ecogeomorphology of coastal wetlands, Estuar. Coasts, 31 (3), 477-491, http://dx.doi.org/10.1007/s12237-008-9047-6.

de Sieyes, N.R., Yamahara, K.M., Layton, B.A., Joyce, E.A., Boehm, E.H., 2008. Submarine discharge of nutrient-enriched fresh groundwater at Stinson Beach, California is enhanced during neap tides, Limnol. Oceanogr., 53, 1434-1445, http://dx.doi.org/10.4319/lo.2008.53.4.1434.

de Weys, J., Santos, I.R., Eyre, B.D., 2011. Linking groundwater discharge to severe estuarine acidification during a flood in a modified wetland, Environ. Sci. Technol., 45 (8), 3310-3316, http://dx.doi.org/10.1021/es104071r. 
Defeo, O., Mclachlan, A., Schoeman, D.S., Schlacher, T.A., Dugan, J., Jones, A., Lastra, M., Scapini, F., 2009. Threats to sandy beach ecosystems: A review, Estuar. Coast. Shelf Sci., 81 (1), 1-12, http://doi.org/10.1016/j.ecss.2008.09.022.

Destouni, G., Prieto, C., 2003. On the possibility for generic modelling of submarine groundwater discharge, Biogeochemistry, 66 (1), 171-186, http://dx.doi.org/10.1023/B:BIOG.0000006101.12076.10.

Destouni, G., Prieto, C. (2010), Submarine groundwater discharge and seawater intrusion: Two sides of the same problem with major quantification gaps, in World Environmental and Water Resources Congress 2010, edited, http://dx.doi.org/10.1061/41114(371)122.

Diaz, R.J., Rosenberg, R., 2008. Spreading dead zones and consequences for marine ecosystems, Science, 321 (5891), 926-929, http://dx.doi.org/10.1126/science.1156401.

Doney, S.C., Fabry, V.J., Feely, R.A., Kleypas, J.A., 2009. Ocean acidification: The other $\mathrm{CO}_{2}$ problem, Ann. Rev. Mar. Sci., 1, 169-192, http://dx.doi.org/10.1146/annurev.marine.010908.163834.

Dulaiova, H., Burnett, W.C., Chanton, J.P., Moore, W.S., Bokuniewicz, H.J., Charette, M.A., Sholkovitz, E., 2006. Assessment of groundwater discharges into West Neck Bay, New York, via natural tracers, Cont. Shelf Res., 26 (16), 1971-1983, http://doi.org/10.1016/j.csr.2006.07.011.

Elfrink, B., Baldock, T., 2002. Hydrodynamics and sediment transport in the swash zone: A review and perspectives, Coast. Eng., 45 (3), 149-167, http://doi.org/10.1016/S03783839(02)00032-7. 
Erler, D.V., Santos, I.R., Eyre, B.D., 2014. Inorganic nitrogen transformations within permeable carbonate sands, Cont. Shelf Res., 77, 69-80, http://doi.org/10.1016/j.csr.2014.02.002.

Evans, T.B., Wilson, A.M., 2016. Groundwater transport and the freshwater-saltwater interface below sandy beaches, J. Hydrol., 538, 563-573, http://doi.org/10.1016/j.jhydrol.2016.04.014.

Ferguson, G., Gleeson, T., 2012. Vulnerability of coastal aquifers to groundwater use and climate change, Nature Clim. Change, 2, 342-345, http://doi.org/10.1038/nclimate1413.

Ganguli, P.M., Conaway, C.H., Swarzenski, P.W., Izbicki, J.A., Flegal, A.R., 2012. Mercury speciation and transport via submarine groundwater discharge at a southern California coastal lagoon system, Environ. Sci. Technol., 46 (3), 1480-1488, http://doi.org/10.1021/es202783u.

Ganguli, P.M., Swarzenski, P.W., Dulaiova, H., Glenn, C.R., Flegal, A.R., 2014. Mercury dynamics in a coastal aquifer: Maunalua Bay, O`ahu, Hawai ${ }^{`}$ i, Estuar. Coast. Shelf Sci., 140, 5265, http://dx.doi.org/10.1016/j.ecss.2014.01.012.

Geng, X., Boufadel, M.C., Xia, Y., Li, H., Zhao, L., Jackson, N.L., Miller, R.S., 2014. Numerical study of wave effects on groundwater flow and solute transport in a laboratory beach, J. Contam. Hydrol., 165, 37-52, http://doi.org/10.1016/j.jconhyd.2014.07.001.

Geng, X., Boufadel, M.C., 2015a. Impacts of evaporation on subsurface flow and salt accumulation in a tidally influenced beach, Water Resour. Res., 51 (7), 5547-5565, http://doi.org/10.1002/2015WR016886. 
Geng, X., Boufadel, M.C., 2015b. Numerical study of solute transport in shallow beach aquifers subjected to waves and tides, J. Geophys. Res.: Oceans, 120 (2), 1409-1428, http://doi.org/10.1002/2014JC010539.

Geng, X., Boufadel, M.C., 2015c. Numerical modeling of water flow and salt transport in bare saline soil subjected to evaporation, J. Hydrol., 524, 427-438, http://doi.org/10.1016/j.jhydrol.2015.02.046.

Geng, X., Boufadel, M.C., Lee, K., Abrams, S., Suidan, M., 2015. Biodegradation of subsurface oil in a tidally influenced sand beach: Impact of hydraulics and interaction with pore water chemistry, Water Resour. Res., 51 (5), 3193-3218, http://doi.org/10.1002/2014WR016870.

Geng, X., Boufadel, M.C., Jackson, N.L., 2016a. Evidence of salt accumulation in beach intertidal zone due to evaporation, Sci. Rep., 6, http://doi.org/10.1038/srep31486.

Geng, X., Pan, Z., Boufadel, M.C., Ozgokmen, T., Lee, K., Zhao, L., 2016b. Simulation of oil bioremediation in a tidally influenced beach: Spatiotemporal evolution of nutrient and dissolved oxygen, J. Geophys. Res.: Oceans, 121 (4), 2385-2404, http://doi.org/10.1002/2015JC011221.

Geng, X., Boufadel, M.C., 2017. Spectral responses of gravel beaches to tidal signals, Sci. Rep., 7, Article number: 40770, http://doi.org/10.1038/srep40770.

Glover, R.E., 1959. The pattern of freshwater flow in a coastal aquifer, J. Geophy. Res., 64 (4), 439-460, http://doi.org/10.1029/JZ064i004p00457. 
Goni, M.A., Gardner, L.R., 2003. Seasonal dynamics in dissolved organic carbon concentrations in a coastal water-table aquifer at the forest-marsh interface, Aquat. Geochem., 9 (3), 209-232, http://doi.org/10.1023/B:AQUA.0000022955.82700.ed.

Gonneea, M.E., Mulligan, A.E., Charette, M.A., 2013a. Seasonal cycles in radium and barium within a subterranean estuary: Implications for groundwater derived chemical fluxes to surface waters, Geochem. Cosmochim. Acta, 119, 164-177, http://dx.doi.org/10.1016/j.gca.2013.05.034.

Gonneea, M.E., Mulligan, A.E., Charette, M.A., 2013b. Climate-driven sea level anomalies modulate coastal groundwater dynamics and discharge, Geophys. Res. Lett., 40 (11), 2701-2706, http://dx.doi.org/10.1002/grl.50192.

Gonneea, M.E., Charette, M.A., 2014. Hydrologic controls on nutrient cycling in an unconfined coastal aquifer, Environ. Sci. Technol., 48 (24), 14178-14185, http://dx.doi.org/10.1021/es503313t.

Greskowiak, J., 2014. Tide-induced salt-fingering flow during submarine groundwater discharge, Geophys. Res. Lett., 41 (18), 6413-6419, http://dx.doi.org/10.1002/2014GL061184.

Guo, Q., Li, H., Boufadel, M.C., Sharifi, Y., 2010. Hydrodynamics in a gravel beach and its impact on the Exxon Valdez oil, J. Geophys. Res.: Oceans, 115, C12077, http://dx.doi.org/10.1029/2010JC006169.

Hallegatte, S., Ranger, N., Mestre, O., Dumas, P., Corfee-Morlot, J., Herweijer, C., Wood, R.M., 2011. Assessing climate change impacts, sea level rise and storm surge risk in port cities: A case study on Copenhagen, Climat. Change, 104 (1), 113-137, http://doi.org/10.1007/s10584-0109978-3. 
Halpern, B.S., Walbridge, S., Selkoe, K.A., Kappel, C.V., Micheli, F., D’Agrosa, C., Bruno, J.F., Casey, K.S., Ebert, C., Fox, H.E., Fujita, R., Heinemann, D., Lenihan, H.S., Madin, E.M.P., Perry, M.T., Selig, E.R., Spalding, M., Steneck, R., Watson, R., 2008. A global map of human impact on marine ecosystems, Science, 319 (5865), 948-952, http://doi.org/10.1126/science.1149345.

Hamilton, S.K., Gehrke, P.C., 2005. Australia's tropical river systems: Current scientific understanding and critical knowledge gaps for sustainable management, Mar. Freshwat. Res., 56 (3), 243-252, http://doi.org/10.1071/MF05063.

Heiss, J.W., Michael, H.A., 2014. Saltwater-freshwater mixing dynamics in a sandy beach aquifer over tidal, spring-neap, and seasonal cycles, Water Resour. Res., 50 (8), http://doi.org/10.1002/2014WR015574.

Heiss, J.W., Ullman, W.J., Michael, H.A., 2014. Swash zone moisture dynamics and unsaturated infiltration in two sandy beach aquifers, Estuar. Coast. Shelf Sci., 143, 20-31, http://doi.org/10.1016/j.ecss.2014.03.015.

Heiss, J.W., Puleo, J.A., Ullman, W.J., Michael, H.A., 2015. Coupled surface-subsurface hydrologic measurements reveal infiltration, recharge, and discharge dynamics across the swash zone of a sandy beach, Water Resour. Res., 51 (11), 8834-8853, http://doi.org/10.1002/2015WR017395.

Holding, S., Allen, D.M., 2015. From days to decades: Numerical modelling of freshwater lens response to climate change stressors on small low-lying islands, Hydrol. Earth Syst. Sci., 19 (2), 933-949, http://doi.org/10.5194/hess-19-933-2015. 
Horn, D., 2006. Measurements and modelling of beach groundwater flow in the swash-zone: A review, Cont. Shelf Res., 26, 622-652, http://doi.org/10.1016/j.csr.2006.02.001.

Horn, D.P., Baldock, T.E., Baird, A.J., Mason, T.E. (1998), Field measurements of swash induced pressures within a sandy beach, paper presented at 26th International Conference on Coastal Engineering, Copenhagen, Denmark.

Hu, C., Muller-Karger, F.E., Swarzenski, P.W., 2006. Hurricanes, submarine groundwater discharge, and Florida's red tides, Geophys. Res. Lett., 33, L11601, http://dx.doi.org/10.1029/2005GL025449.

Ibánhez, J.S.P., Rocha, C., 2017. Kinetics of inorganic nitrogen turnover in a sandy seepage face on a subterranean estuary, Appl. Geochem., http://doi.org/10.1016/j.apgeochem.2017.10.015.

Idso, S., Reginato, R., Jackson, R., Kimball, B., Nakayama, F., 1974. The three stages of drying of a field soil, Soil Sci. Soc. Am. J., 38 (5), 831-837, http://doi.org/10.2136/sssaj1974.03615995003800050037x.

International Panel on Climate Change, 2013. Climate Change 2013: The Physical Science Basis. Working Group 1 Contribution to the Fifth Assessment Report of the International Panel on Climate Change, Cambridge, New York.

Jeffrey, L.C., Maher, D.T., Santos, I.R., McMahon, A., Tait, D.R., 2016. Groundwater, acid and carbon dioxide dynamics along a coastal wetland, lake and estuary continuum, Estuar. Coasts, 39 (5), 1325-1344, http://doi.org/10.1007/s12237-016-0099-8. 
Jeong, J., Kim, G., Han, S., 2012. Influence of trace element fluxes from submarine groundwater discharge (SGD) on their inventories in coastal waters off volcanic island, Jeju, Korea, Appl. Geochem., 27 (1), 37-43, http://doi.org10.1016/j.apgeochem.2011.08.014.

Johannes, R.E., 1980. The ecological significance of the submarine discharge of groundwater, Mar. Ecol. Prog. Ser., 3, 365-373, http://doi.org/10.3354/meps003365.

Johannesson, K.H., Neumann, K., 2013. Geochemical cycling of mercury in a deep, confined aquifer: Insights from biogeochemical reactive transport modeling, Geochem. Cosmochim. Acta, 106, 25-43, http://doi.org/10.1016/j.gca.2012.12.010.

Jung, H.B., Charette, M.A., Zheng, Y., 2009. Field, laboratory and modeling study of reactive transport in groundwater arsenic in a coastal aquifer, Environ. Sci. Technol., 43, 5333-5338, http://doi.org/10.1021/es900080q.

Kelly, R.P., Moran, S.B., 2002. Seasonal changes in groundwater input to a well-mixed estuary estimated using radium isotopes and implications for coastal nutrient budgets, Limnol. Oceanogr., 47 (6), 1796-1807, http://doi.org/10.4319/lo.2002.47.6.1796.

Ketabchi, H., Mahmoodzadeh, D., Ataie-Ashtiani, B., Simmons, C.T., 2016. Sea-level rise impacts on seawater intrusion in coastal aquifers: Review and integration, J. Hydrol., 535, 235255, http://dx.doi.org/10.1016/j.jhydrol.2016.01.083.

Kim, G., Hwang, D.W., 2002. Tidal pumping of groundwater into the coastal ocean revealed from submarine ${ }^{222} \mathrm{Rn}$ and $\mathrm{CH}_{4}$ monitoring, Geophys. Res. Lett., 29 (14), 1678, http://doi.org/10.1029/2002GL015093. 
King, J.N., 2012. Synthesis of benthic flux components in the Patos Lagoon coastal zone, Rio Grande do Sul, Brazil, Water Resour. Res., 48, 10.1029/2011wr011477.

Knee, K.L., Paytan, A. (2012), 4.08 - Submarine groundwater discharge: A source of nutrients, metals, and pollutants to the coastal ocean, in Treatise on Estuarine and Coastal Science, edited, pp. 205-233, Academic Press, Waltham, http://doi.org/10.1016/B978-0-12-374711-2.00410-1.

Knutson, T.R., McBride, J.L., Chan, J., Emanuel, K., Holland, G., Landsea, C., Held, I., Kossin, J.P., Srivastava, A.K., Sugi, M., 2010. Tropical cyclones and climate change, Nature Geosci, 3 (3), 157-163, http://dx.doi.org/10.1038/ngeo779.

Kroeger, K.D., Charette, M.A., 2008. Nitrogen biogeochemistry of submarine groundwater discharge, Limnol. Oceanogr., 53 (3), 1025-1039, http://dx.doi.org/10.4319/1o.2008.53.3.1025.

Kuan, W.K., Jin, G., Xin, P., Robinson, C., Gibbes, B., Li, L., 2012. Tidal influence on seawater intrusion in unconfined coastal aquifers, Water Resour. Res., 48(2), W02502, http://dx.doi.org/10.1029/2011WR010678.

Kundzewicz, Z.W., Doli, P., 2009. Will groundwater ease freshwater stress under climate change? Hydrol. Sci. J., 54 (4), 665-675, http://dx.doi.org/10.1623/hysj.54.4.665.

Kwon, E.Y., Kim, G., Primeau, F., Moore, W.S., Cho, H.-M., DeVries, T., Sarmiento, J.L., Charette, M.A., Cho, Y.-K., 2014. Global estimate of submarine groundwater discharge based on an observationally constrained radium isotope model, Geophys. Res. Lett., 41 (23), 8438-8444, http://doi.org/10.1002/2014GL061574. 
Lanyon, J.A., Elliot, I.G., Clarke, D.J., 1982. Groundwater-level variation during semidiurnal spring tidal cycles on a sandy beach, Aust. J. Mar. Freshwat. Res., 33, 377-300, http://dx.doi.org/10.1071/MF9820377.

Laurier, F.J.G., Cossa, D., Beucher, C., Brévière, E., 2007. The impact of groundwater discharges on mercury partitioning, speciation and bioavailability to mussels in a coastal zone, Mar. Chem., 106 (SI 1-2), 352-364, http://dx.doi.org/10.1016/j.marchem.2007.06.007.

Lebbe, L.C. (1981), The subterranean flow of fresh and salt water underneath the western Belgian beach, paper presented at 7th Salt Water Intrusion Meeting, Uppsala, Sweden, 14-17 September.

Lecher, A.L., Kessler, J., Sparrow, K., Garcia-Tigreros Kodovska, F., Dimova, N., Murray, J., Tulaczyk, S., Paytan, A., 2016. Methane transport through submarine groundwater discharge to the North Pacific and Arctic Ocean at two Alaskan sites, Limnol. Oceanogr., 61 (S1), S344S355, http://dx.doi.org/10.1002/1no.10118.

Lee, C.M., Jiao, J.J., Luo, X., Moore, W.S., 2012. Estimation of submarine groundwater discharge and associated nutrient fluxes in Tolo Harbour, Hong Kong, Sci. Total. Environ., 433, 427-433, http://doi.org/10.1016/j.scitotenv.2012.06.073.

Lee, J., Kim, G., 2015. Dependence of $\mathrm{pH}$ in coastal waters on the adsorption of protons onto sediment minerals, Limnol. Oceanogr., 60 (3), 831-839, http://doi.org/10.1002/lno.10057.

Lee, Y.-W., Hwang, D.-W., Kim, G., Lee, W.-C., Oh, H.-T., 2009. Nutrient inputs from submarine groundwater discharge (SGD) in Masan Bay, an embayment surrounded by heavily 
industrialized cities, Korea, Sci. Total. Environ., 407 (9), 3181-3188, http://doi.org/10.1016/j.scitotenv.2008.04.013.

Lee, Y.G., Rahman, M.M., Kim, G., Han, S., 2011. Mass balance of total mercury and monomethylmercury in coastal embayments of a volcanic island: Significance of submarine groundwater discharge, Environ. Sci. Technol., 45 (23), 9891-9900, http://doi.org/10.1021/es202093z.

Lee, Y.W., Kim, G., Lim, W.A., Hwang, D.W., 2010. A relationship between submarine groundwater-borne nutrients traced by Ra isotopes and the intensity of dinoflagellate red-tides occurring in the southern sea of Korea, Limnol. Oceanogr., 55 (1), 1-10, http://doi.org/10.4319/1o.2010.55.1.0001.

Leeks, G.J.L., Jarvie, H.P., 1998. Introduction to the land-ocean interaction study (LOIS): Rationale and international context, Sci. Total. Environ., 210-211, 5-20, http://dx.doi.org/10.1016/S0048-9697(98)00041-2.

Li, H., Boufadel, M.C., Weaver, J.W., 2008. Tide-induced seawater-groundwater circulation in shallow beach aquifers, J. Hydrol., 352 (1-2), 211-224, http://dx.doi.org/10.1016/j.jhydrol.2008.01.013.

Li, H., Boufadel, M.C., 2010. Long-term persistence of oil from the Exxon Valdez spill in twolayer beaches, Nature Geosci, 3 (2), 96-99, http://www.nature.com/ngeo/journal/v3/n2/suppinfo/ngeo749_S1.html. 
Li, L., Barry, D.A., Stagnitti, F., Parlange, J.-Y., 1999. Submarine groundwater discharge and associated chemical input to a coastal sea, Water Resour. Res., 35 (11), 3253-3259, http://dx.doi.org/10.1029/1999WR900189.

Li, L., Barry, D.A., 2000. Wave-induced beach groundwater flow, Adv. Water Resour., 23 (4), 325-337, http://dx.doi.org/10.1016/S0309-1708(99)00032-9.

Li, L., Barry, D.A., Stagnitti, F., Parlange, J.Y., Jeng, D.S., 2000. Beach water table fluctuations due to spring-neap tides: moving boundary effects, Adv. Water Resour., 23 (8), 817-824, http://dx.doi.org/10.1016/s0309-1708(00)00017-8.

Li, X., Hu, B.X., Burnett, W.C., Santos, I.R., Chanton, J.P., 2009. Submarine ground water discharge driven by tidal pumping in a heterogeneous aquifer, Ground Water, 47 (4), 558-568, http://dx.doi.org/10.1111/j.1745-6584.2009.00563.x.

Li, X., Hu, B.X., Tong, J., 2016. Numerical study on tide-driven submarine groundwater discharge and seawater recirculation in heterogeneous aquifers, Stoch. Environ. Res. Risk Assess., 30 (6), 1741-1755, http://dx.doi.org/10.1007/s00477-015-1200-8.

Liu, Q., Charette, M.A., Breier, C.F., Henderson, P.B., McCorkle, D.C., Martin, W., Dai, M., 2017. Carbonate system biogeochemistry in a subterranean estuary - Waquoit Bay, USA, Geochem. Cosmochim. Acta, 203, 422-439, http://dx.doi.org/10.1016/j.gca.2017.01.041.

Liu, Y., Jiao, J.J., Luo, X., 2016. Effects of inland water level oscillation on groundwater dynamics and land-sourced solute transport in a coastal aquifer, Coast. Eng., 114, 347-360, http://doi.org/10.1016/j.coastaleng.2016.04.021. 
Longuet-Higgins, M.S., 1983. Wave set-up, percolation and undertow in the surf zone, Proc.

Royal Soc. Lond. A, 390 (1799), 283-291, http://dx.doi.org/10.1098/rspa.1983.0132.

Loveless, A.M., Oldham, C.E., Hancock, G.J., 2008. Radium isotopes reveal seasonal groundwater inputs to Cockburn Sound, a marine embayment in Western Australia, J. Hydrol., 351 (1-2), 203-217, http://dx.doi.org/10.1016/j.jhydrol.2007.12.010.

Loveless, A.M., Oldham, C.E., 2010. Natural attenuation of nitrogen in groundwater discharging through a sandy beach, Biogeochemistry, 98(1-3), 75-87, http://dx.doi.org/10.1007/s10533-0099377-x.

Lu, C., Kitanidis, P.K., Luo, J., 2009. Effects of kinetic mass transfer and transient flow conditions on widening mixing zones in coastal aquifers, Water Resour. Res., 45 (12), W12402, http://dx.doi.org/10.1029/2008WR007643.

Lu, C., Werner, A.D., 2013. Timescales of seawater intrusion and retreat, Adv. Water Resour., 59, 39-51, http://dx.doi.org/10.1016/j.advwatres.2013.05.005.

Luo, X., Jiao, J.J., Moore, W.S., Lee, C.M., 2014. Submarine groundwater discharge estimation in an urbanized embayment in Hong Kong via short-lived radium isotopes and its implication of nutrient loadings and primary production, Mar. Pollut. Bull., 82 (1-2), 144-154, http://dx.doi.org/10.1016/j.marpolbul.2014.03.005.

Malott, S., O’Carroll, D.M., Robinson, C.E., 2016. Dynamic groundwater flows and geochemistry in a sandy nearshore aquifer over a wave event, Water Resour. Res., 52 (7), 52485264, http://dx.doi.org/10.1002/2015WR017537. 
Malott, S., O'Carroll, D.M., Robinson, C.E., 2017. Influence of instantaneous and time-averaged groundwater flows induced by waves on the fate of contaminants in a beach aquifer, Water Resour. Res., http://doi.org/10.1002/2017WR020948.

Mango, A.J., Schmeeckle, M.W., Furbish, D.J., 2004. Tidally induced groundwater circulation in an unconfined coastal aquifer modeled with a Hele-Shaw cell, Geology, 32 (3), 233-236, http://dx.doi.org/10.1130/G19922.1

Mao, X., Enot, P., Barry, D.A., Li, L., Binley, A., Jeng, D.-S., 2006. Tidal influence on behaviour of a coastal aquifer adjacent to a low-relief estuary, J. Hydrol., 327 (1-2), 110-127, http://dx.doi.org/10.1016/j.jhydrol.2005.11.030.

Masselink, G., Hughes, M., 1998. Field investigation of sediment transport in the swash zone, Cont. Shelf Res., 18 (10), 1179-1199, http://dx.doi.org/10.1016/S0278-4343(98)00027-2.

Mastrocicco, M., Colombani, N., Sbarbati, C., Petitta, M., 2012. Assessing the effect of saltwater intrusion on petroleum hydrocarbons plumes via numerical modelling, Water, Air, \& Soil Pollution, 223 (7), 4417-4427, http://doi.org/10.1007/s11270-012-1205-6.

McGranahan, G., Balk, D., Anderson, B., 2007. The rising tide: Assessing the risks of climate change and human settlements in low elevation coastal zones, Environ. Urbaniz., 19 (1), 17-37, http://dx.doi.org/10.1177/0956247807076960.

Michael, H.A., Mulligan, A.E., Harvey, C.F., 2005. Seasonal oscillations in water exchange between aquifers and the coastal ocean, Nature, 436, 1145-1148, http://dx.doi.org/10.1038/nature03935. 
Michael, H.A., Russoniello, C.J., Byron, L.A., 2013. Global assessment of vulnerability to sealevel rise in topography-limited and recharge-limited coastal groundwater systems, Water Resour. Res., 49 (4), 2228-2240, http://dx.doi.org/10.1002/wrcr.20213.

Millero, F.J., 2007. The marine inorganic carbon cycle, Chem. Rev., 107 (2), 308-341, http://dx.doi.org/10.1021/cr0503557.

Miyaoka, K. (2007), Seasonal changes in the groundwater-seawater interaction and its relation to submarine groundwater discharge, Ise Bay, Japan, paper presented at IAHS-AISH Publication.

Moore, W.S., 1996. Large groundwater inputs to coastal waters revealed by ${ }^{226} \mathrm{Ra}$ enrichments, Nature, 380, 612-614, http://dx.doi.org/10.1038/380612a0.

Moore, W.S., 1999. The subterranean estuary: A reaction zone of ground water and sea water, Mar. Chem., 65 (1-2), 111-125, http://dx.doi.org/10.1016/S0304-4203(99)00014-6.

Moore, W.S. (2007), Seasonal changes in the radium-226 distribution on the southeastern USA continental shelf: Implications for changing submarine groundwater discharge, paper presented at IAHS-AISH Publication.

Moore, W.S., Sarmiento, J.L., Key, R.M., 2008. Submarine groundwater discharge revealed by ${ }^{228} \mathrm{Ra}$ distribution in the upper Atlantic Ocean, Nat. Geosci., 1, 309-311, http://dx.doi.org/10.1038/ngeo183.

Moore, W.S., Shaw, T.J., 2008. Fluxes and behavior of radium isotopes, barium, and uranium in seven Southeastern US rivers and estuaries, Mar. Chem., 108 (3-4), 236-254, http://dx.doi.org/10.1016/j.marchem.2007.03.004. 
Moore, W.S., 2010. The effect of submarine groundwater discharge on the ocean, Ann. Rev. Mar. Sci., 2 (1), 59-88, http://dx.doi.org/10.1146/annurev-marine-120308-081019.

Nachshon, U., Shahraeeni, E., Or, D., Dragila, M., Weisbrod, N., 2011. Infrared thermography of evaporative fluxes and dynamics of salt deposition on heterogeneous porous surfaces, Water Resour. Res., 47 (12), W12519, http://dx.doi.org/10.1029/2011wr010776.

National Research Council (2013), An ecosystem services approach to assessing the impacts of the deepwater horizon oil spill in the Gulf of Mexico, National Academy Press, Washington, D.C.

Neumann, B., Vafeidis, A.T., Zimmermann, J., Nicholls, R.J., 2015. Future coastal population growth and exposure to sea-level rise and coastal flooding - A global assessment, PLOS ONE, 10 (3), e0118571, http://dx.doi.org/10.1371/journal.pone.0118571.

Newton, A., Mudge, S.M., 2005. Lagoon-sea exchanges, nutrient dynamics and water quality management of the Ria Formosa (Portugal), Estuar. Coast. Shelf Sci., 62 (3), 405-414, http://dx.doi.org/10.1016/j.ecss.2004.09.005.

Nielsen, P., 1990. Tidal dynamics of the water table in beaches, Water Resour. Res., 26 (9), 2127-2134, http://dx.doi.org/10.1029/WR026i009p02127.

Nielsen, P., 1999. Groundwater dynamics and salinity in coastal barriers, J. Coastal Res., 15 (3), 732-740, http://www.jstor.org/stable/4298987. 
O'Connor, A.E., Luek, J.L., McIntosh, H., Beck, A.J., 2015. Geochemistry of redox-sensitive trace elements in a shallow subterranean estuary, Mar. Chem., 172, 70-81, http://dx.doi.org/10.1016/j.marchem.2015.03.001.

O'Reilly, C., Santos, I.R., Cyronak, T., McMahon, A., Maher, D.T., 2015. Nitrous oxide and methane dynamics in a coral reef lagoon driven by pore water exchange: Insights from automated high-frequency observations, Geophys. Res. Lett., 42 (8), 2885-2892, http://dx.doi.org/10.1002/2015GL063126.

Owens, E.H., Taylor, E., Humphrey, B., 2008. The persistence and character of stranded oil on coarse-sediment beaches, Mar. Pollut. Bull., 56 (1), 14-26, http://dx.doi.org/10.1016/j.marpolbul.2007.08.020.

Parlange, J.-Y., Stagnitti, F., Starr, J.L., Braddock, R.D., 1984. Free surface flow in porous media and periodic solution of shallow-flow approximation, J. Hydrol., 70 (1-4), 251-263, http://dx.doi.org/10.1016/0022-1694(84)90125-2.

Paytan, A., Shellenbarger, G.G., Street, J.H., Gonneea, M.E., Davis, K., Young, M.B., Moore, W.S., 2006. Submarine groundwater discharge: An important source of new inorganic nitrogen to coral reef ecosystems, Limnol. Oceanogr., 51 (1), 343-348, http://dx.doi.org/10.4319/lo.2006.51.1.0343.

Penman, H.L., 1948. Natural evaporation from open water, bare soil and grass, Proc. Royal Soc. Lond. A, 193 (1032), 120-145, http://dx.doi.org/10.1098/rspa.1948.0037. 
Pool, M., Post, V.E.A., Simmons, C.T., 2014. Effects of tidal fluctuations on mixing and spreading in coastal aquifers: Homogeneous case, Water Resour. Res., 50 (8), 6910-6926, http://dx.doi.org/10.1002/2014WR015534.

Pool, M., Post, V.E.A., Simmons, C.T., 2015. Effects of tidal fluctuations and spatial heterogeneity on mixing and spreading in spatially heterogeneous coastal aquifers, Water Resour. Res., 51 (3), 1570-1585, http://dx.doi.org/10.1002/2014WR016068.

Porubsky, W.P., Weston, N.B., Moore, W.S., Ruppel, C., Joye, S.B., 2014. Dynamics of submarine groundwater discharge and associated fluxes of dissolved nutrients, carbon, and trace gases to the coastal zone (Okatee River estuary, South Carolina), Geochem. Cosmochim. Acta, 131, 81-97, http://dx.doi.org/10.1016/j.gca.2013.12.030.

Post, V.E.A., Vandenbohede, A., Werner, A.D., Maimun, Teubner, M.D., 2013. Groundwater ages in coastal aquifers, $A d v$. Water Resour., 57, 1-11, http://dx.doi.org/10.1016/j.advwatres.2013.03.011.

Qu, W., Li, H., Wan, L., Wang, X., Jiang, X., 2014. Numerical simulations of steady-state salinity distribution and submarine groundwater discharges in homogeneous anisotropic coastal aquifers, Adv. Water Resour., 74, 318-328, http://dx.doi.org/10.1016/j.advwatres.2014.10.009.

Rahman, M.D.M., Lee, Y.G., Kim, G., Lee, K., Han, S., 2013. Significance of submarine groundwater discharge in the coastal fluxes of mercury in Hampyeong Bay, Yellow Sea, Chemosphere, 91 (3), 320-327, http://dx.doi.org/10.1016/j.chemosphere.2012.11.052.

Ramsay, J.O., Silverman, B.W. (2005), Functional Data Analysis, Springer, New York. 
Rapaglia, J.P., Bokuniewicz, H.J., 2009. The effect of groundwater advection on salinity in pore waters of permeable sediments, Limnol. Oceanogr., 54 (2), 630-643, http://doi.org/10.4319/1o.2009.54.2.0630.

Reckhardt, A., Beck, M., Seidel, M., Riedel, T., Wehrmann, A., Bartholomä, A., Schnetger, B., Dittmar, T., Brumsack, H.-J., 2015. Carbon, nutrient and trace metal cycling in sandy sediments: A comparison of high-energy beaches and backbarrier tidal flats, Estuar. Coast. Shelf Sci., 159, 1-14, http://dx.doi.org/10.1016/j.ecss.2015.03.025.

Robinson, C., Gibbes, B., Li, L., 2006. Driving mechanisms for flow and salt transport in a subterranean estuary, Geophys. Res. Lett., 33 (3), L03402, http://dx.doi.org/10.1029/2005GL025247.

Robinson, C., Gibbes, B., Carey, H., Li, L., 2007a. Salt-freshwater dynamics in a subterranean estuary over a spring-neap tidal cycle, J. Geophy. Res., 112 (C9), C09007, http://dx.doi.org/10.1029/2006JC003888.

Robinson, C., Li, L., Barry, D.A., 2007b. Effect of tidal forcing on a subterranean estuary, Adv. Water Resour., 30(4), 851-865, http://dx.doi.org/10.1016/j.advwatres.2006.07.006.

Robinson, C., Li, L., Prommer, H., 2007c. Tide-induced recirculation across the aquifer-ocean interface, Water Resour. Res., 43, W07428, http://dx.doi.org/10.1029/2006WR005679.

Robinson, C., Brovelli, A., Barry, D.A., Li, L., 2009. Tidal influence on BTEX biodegradation in sandy coastal aquifers, Adv. Water Resour., 32 (1), 16-28, http://dx.doi.org/10.1016/j.advwatres.2008.09.008. 
Robinson, C., Xin, P., Li, L., Barry, D.A., 2014. Groundwater flow and salt transport in a subterranean estuary driven by intensified wave conditions, Water Resour. Res., 50, 1-17, http://dx.doi.org/10.1002/2013WR013813.

Robinson, M.A., Gallagher, D., Reay, W., 1998. Field observations of tidal and seasonal variations in groundwater discharge to tidal estuarine surface water, Ground Water Monit. Remediat., 18 (1), 83-92, http://dx.doi.org/10.1111/j.1745-6592.1998.tb00605.x.

Rodellas, V., Garcia-Orellana, J., Masqué, P., Feldman, M., Weinstein, Y., 2015. Submarine groundwater discharge as a major source of nutrients to the Mediterranean Sea, Proc. Natl. Acad. Sci. USA, 112 (13), 3926-3930, http://dx.doi.org/10.1073/pnas.1419049112.

Röper, T., Greskowiak, J., Massmann, G., 2015. Instabilities of submarine groundwater discharge under tidal forcing, Limnol. Oceanogr., 60 (1), 22-28, http://dx.doi.org/10.1002/lno.10005.

Roy, M., Martin, J.B., Cherrier, J., Cable, J.E., Smith, C.G., 2010. Influence of sea level rise on iron diagenesis in an east Florida subterranean estuary, Geochem. Cosmochim. Acta, 74 (19), 5560-5573, http://dx.doi.org/10.1016/j.gca.2010.07.007.

Roy, M., Martin, J.B., Cable, J.E., Smith, C.G., 2013. Variations of iron flux and organic carbon remineralization in a subterranean estuary caused by inter-annual variations in recharge, Geochem. Cosmochim. Acta, 103, 301-315, http://dx.doi.org/10.1016/j.gca.2012.10.055.

Russoniello, C.J., Fernandez, C., Bratton, J.F., Banaszak, J.F., Krantz, D.E., Andres, A.S., Konikow, L.F., Michael, H.A., 2013. Geologic effects on groundwater salinity and discharge 
into an estuary, J. Hydrol., 498 (Supplement C), 1-12,

https://doi.org/10.1016/j.jhydrol.2013.05.049.

Sadat-Noori, M., Maher, D.T., Santos, I.R., 2016a. Groundwater discharge as a source of dissolved carbon and greenhouse gases in a subtropical estuary, Estuar. Coasts, 39 (3), 639-656, http://dx.doi.org/10.1007/s12237-015-0042-4.

Sadat-Noori, M., Santos, I.R., Tait, D.R., Maher, D.T., 2016b. Fresh meteoric versus recirculated saline groundwater nutrient inputs into a subtropical estuary, Sci. Total. Environ., 566-567, 1440-1453, http://dx.doi.org/10.1016/j.scitotenv.2016.06.008.

Sallenger, A.H., Doran, K.S., Howd, P.A., 2012. Hotspot of accelerated sea-level rise on the Atlantic coast of North America, Nat. Clim. Change, 2 (12), 884-888, http://dx.doi.org/10.1038/nclimate1597.

Sanford, W.E., Pope, J.P., 2013. Quantifying groundwater's role in delaying improvements to Chesapeake Bay water quality, Environ. Sci. Technol., 47 (23), 13330-13338, http://dx.doi.org/10.1021/es401334k.

Santoro, A.E., Francis, C.A., Sieyes, N.R., Boehm, A.B., 2008. Shifts in the relative abundance of ammonia-oxidizing bacteria and archaea across physicochemical gradients in a subterranean estuary, Environ. Microbiol., 10 (4), 1068-1079, http://dx.doi.org/10.1111/j.14622920.2007.01547.x.

Santos, I.R., Burnett, W.C., Chanton, J., Mwashote, B., Suryaputra, I., Dittmar, T., 2008. Nutrient biogeochemistry in a Gulf of Mexico subterranean estuary and groundwater-derived 
fluxes to the coastal ocean, Limnol. Oceanogr., 53 (2), 705-718, http://dx.doi.org/10.4319/1o.2008.53.2.0705.

Santos, I.R., Burnett, W.C., Chanton, J., Dimova, N., Mwashote, B., Peterson, R., 2009a.

Extended time series measurements of submarine groundwater discharge tracers $\left({ }^{222} \mathrm{Rn}\right.$ and $\left.\mathrm{CH}_{4}\right)$ at a coastal site in Florida, Mar. Chem., 113, 137-147, http://dx.doi.org/10.1016/j.marchem.2009.01.009.

Santos, I.R., Burnett, W.C., Chanton, J., Dimova, N., Peterson, R., 2009b. Land or ocean?: Assessing the driving forces of submarine groundwater discharge at a coastal site in the Gulf of Mexico, J. Geophy. Res., 114 (C4), C04012, http://dx.doi.org/10.1029/2008JC005038.

Santos, I.R., Dimova, N., Peterson, R.N., Mwashote, B., Chanton, J., Burnett, W.C., 2009c. Extended time series measurements of submarine groundwater discharge tracers $(222 \mathrm{Rn}$ and $\mathrm{CH}$ 4) at a coastal site in Florida, Mar. Chem., 113 (1), 137-147, 10.1016/j.marchem.2009.01.009.

Santos, I.R., Burnett, W.C., Misra, S., Suryaputra, I.G.N.A., Chanton, J.P., Dittmar, T., Peterson, R.N., Swarzenski, P.W., 2011a. Uranium and barium cycling in a salt wedge subterranean estuary: The influence of tidal pumping, Chem. Geol., 287 (1-2), 114-123, http://dx.doi.org/10.1016/j.chemgeo.2011.06.005.

Santos, I.R., De Weys, J., Eyre, B.D., 2011b. Groundwater or floodwater?: Assessing the pathways of metal exports from a coastal acid sulfate soil catchment, Environ. Sci. Technol., 45 (22), 9641-9648, http://dx.doi.org/10.1021/es202581h.

Santos, I.R., Cook, P.L.M., Rogers, L., de Weys, J., Eyre, B.D., 2012a. The 'salt wedge pump': Convection-driven porewater exchange as a source of dissolved organic and inorganic carbon 
and nitrogen to an estuary, Limnol. Oceanogr., 57 (5), 1415-1426, http://dx.doi.org/10.4319/1o.2012.57.5.1415.

Santos, I.R., Eyre, B.D., Huettel, M., 2012b. The driving forces of porewater and groundwater flow in permeable coastal sediments: A review, Estuar. Coast. Shelf Sci., 98, 1-15, 10.1016/j.ecss.2011.10.024.

Santos, I.R., Eyre, B.D., Huettel, M., 2012c. The driving forces of porewater and groundwater flow in permeable coastal sediments: A review, Estuar. Coast. Shelf Sci., 98, 1-15, http://doi.org/10.1016/j.ecss.2011.10.024.

Santos, I.R., de Weys, J., Tait, D.R., Eyre, B.D., 2013. The contribution of groundwater discharge to nutrient exports from a coastal catchment: Post-flood seepage increases estuarine N/P ratios, Estuar. Coasts, 36 (1), 56-73, http://dx.doi.org/10.1007/s12237-012-9561-4.

Santos, I.R., Bryan, K.R., Pilditch, C.A., Tait, D.R., 2014. Influence of porewater exchange on nutrient dynamics in two New Zealand estuarine intertidal flats, Mar. Chem., 167, 57-70, http://dx.doi.org/10.1016/j.marchem.2014.04.006.

Santos, I.R., Burnett, W.C., Dittmar, T., Suryaputra, I., Chanton, J., 2009d. Tidal pumping drives nutrient and dissolved organic matter dynamics in a Gulf of Mexico subterranean estuary, Geochem. Cosmochim. Acta, 73, 1325-1339, http://dx.doi.org/10.1016/j.gca.2008.11.029.

Sawyer, A.H., David, C.H., Famiglietti, J.S., 2016. Continental patterns of submarine groundwater discharge reveal coastal vulnerabilities, Science, 353 (6300), 705-707, http://doi.org/10.1126/science.aag1058. 
Sbarbati, C., Colombani, N., Mastrocicco, M., Aravena, R., Petitta, M., 2015. Performance of different assessment methods to evaluate contaminant sources and fate in a coastal aquifer, Environmental Science and Pollution Research, 22 (20), 15536-15548, 10.1007/s11356-0154731-0.

Scavia, D., Field, J.C., Boesch, D.F., Buddemeier, R.W., Burkett, V., Cayan, D.R., Fogarty, M., Harwell, M.A., Howarth, R.W., Mason, C., Reed, D.J., Royer, T.C., Sallenger, A.H., Titus, J.G., 2002. Climate change impacts on U.S. coastal and marine ecosystems, Estuaries, 25 (2), 149164, http://dx.doi.org/10.1007/bf02691304.

Shellenbarger, G.G., Monismith, S.G., Genin, A., Paytan, A., 2006. The importance of submarine groundwater discharge to the near shore nutrient supply in the Gulf of Aqaba (Israel), Limnol. Oceanogr., 51 (4), 1876-1886, http://dx.doi.org/10.4319/lo.2006.51.4.1876.

Shokri, N., Or, D., 2011. What determines drying rates at the onset of diffusion controlled stage2 evaporation from porous media? Water Resour. Res., 47 (9), W09513, http://dx.doi.org/10.1029/2010wr010284.

Sholkovitz, E., Herbold, C., Charette, M., 2003. An automated dye-dilution based seepage meter for the time-series measurement of submarine groundwater discharge, Limnol. Oceanogr. Meth., 1 (1), 16-28, http://dx.doi.org/10.4319/lom.2003.1.16.

Slomp, C.P., Van Cappellen, P., 2004. Nutrient inputs to the coastal ocean through submarine groundwater discharge: controls and potential impact, J. Hydrol., 295 (1-4), 64-86, http://dx.doi.org/10.1016/j.jhydrol.2004.02.018. 
Smith, A.J., 2004. Mixed convection and density-dependent seawater circulation in coastal aquifers, Water Resour. Res., 40(8), W08309, http://dx.doi.org/10.1029/2003WR002977.

Smith, C.G., Cable, J.E., Martin, J.B., 2008. Episodic high intensity mixing events in a subterranean estuary: Effects of tropical cyclones, Limnol. Oceanogr., 53 (2), 666-674, http://dx.doi.org/10.4319/1o.2008.53.2.0666.

Sous, D., Petitjean, L., Bouchette, F., Rey, V., Meulé, S., Sabatier, F., Martins, K., 2016. Field evidence of swash groundwater circulation in the microtidal Rousty beach, France, Adv. Water Resour., 97, 144-155, http://dx.doi.org/10.1016/j.advwatres.2016.09.009.

Spiteri, C., Regnier, P., Slomp, C.P., Charette, M.A., 2006. pH-dependent iron oxide precipitation in a subterranean estuary, J. Geochem. Explor., 88 (1-3), 399-403, http://dx.doi.org/10.1016/j.gexplo.2005.08.084.

Spiteri, C., Slomp, C., Tuncay, K., Meile, C., 2008a. Modeling biogeochemical processes in subterranean estuaries: Effect of flow dynamics and redox conditions on submarine groundwater discharge of nutrients, Water Resour. Res., 44 (2), W04701, http://dx.doi.org/10.1029/2007WR006071.

Spiteri, C., Slomp, C.P., Charette, M.A., Tuncay, K., Meile, C., 2008b. Flow and nutrient dynamics in a subterranean estuary (Waquoit Bay, MA, USA): Field data and reactive transport modeling, Geochem. Cosmochim. Acta, 72 (14), 3398-3412, http://dx.doi.org/10.1016/j.gca.2008.04.027.

Stalker, J.C., Price, R.M., Swart, P.K., 2009. Determining spatial and temporal inputs of freshwater, including submarine groundwater discharge, to a subtropical estuary using 
geochemical tracers, Biscayne Bay, South Florida, Estuar. Coasts, 32 (4), 694-708, http://dx.doi.org/10.1007/s12237-009-9155-y.

Su, N., Du, J., Moore, W.S., Liu, S., Zhang, J., 2011. An examination of groundwater discharge and the associated nutrient fluxes into the estuaries of eastern Hainan Island, China using ${ }^{226} \mathrm{Ra}$, Sci. Total. Environ., 409 (19), 3909-3918, http://dx.doi.org/10.1016/j.scitotenv.2011.06.017.

Sugimoto, R., Honda, H., Kobayashi, S., Takao, Y., Tahara, D., Tominaga, O., Taniguchi, M., 2016. Seasonal changes in submarine groundwater discharge and associated nutrient transport into a tideless semi-enclosed embayment (Obama Bay, Japan), Estuar. Coasts, 39 (1), 13-26, http://dx.doi.org/10.1007/s12237-015-9986-7.

Szymczycha, B., Miotk, M., Pempkowiak, J., 2013. Submarine groundwater discharge as a source of mercury in the Bay of Puck, the southern Baltic Sea, Water Air Soil Poll., 224 (6), http://dx.doi.org/10.1007/s11270-013-1542-0.

Tait, D.R., Erler, D.V., Santos, I.R., Cyronak, T.J., Morgenstern, U., Eyre, B.D., 2014. The influence of groundwater inputs and age on nutrient dynamics in a coral reef lagoon, Mar. Chem., 166 (0), 36-47, http://dx.doi.org/10.1016/j.marchem.2014.08.004.

Tamborski, J.J., Cochran, J.K., Bokuniewicz, H.J., 2017. Application of ${ }^{224} \mathrm{Ra}$ and ${ }^{222} \mathrm{Rn}$ for evaluating seawater residence times in a tidal subterranean estuary, Mar. Chem., 189, 32-45, http://dx.doi.org/10.1016/j.marchem.2016.12.006.

Taniguchi, M., 2002. Tidal effects on submarine groundwater discharge into the ocean, Geophys. Res. Lett., 29 (12, 2-1 - 2-2, ), http://dx.doi.org/10.1029/2002GL014987. 
Taniguchi, M., Burnett, W.C., Cable, J.E., Turner, J.V., 2002. Investigation of submarine groundwater discharge, Hydrolog. Proc., 16, 2115-2129, http://dx.doi.org/10.1002/hyp.1145.

Taniguchi, M., Burnett, W.C., Cable, J.E., Turner, J.V. (2003), Assessment methodologies for submarine groundwater discharge, in Land and Marine Hydrogeology, edited, pp. 1-23, 10.1016/B978-044451479-0/50014-5.

Taniguchi, M., Ishitobi, T., Shimada, J., 2006. Dynamics of submarine groundwater discharge and fresh-seawater interface, J. Geophy. Res., 111 (C1), C01008, http://dx.doi.org/10.1029/2005JC002924.

Thorn, P., Urish, D., 2013. Preliminary observation of complex salt-fresh water mixing in a beach aquifer, GroundWater, 51 (1), 145-150, http://dx.doi.org/10.1111/j.17456584.2012.00947.x.

Trezzi, G., Garcia-Orellana, J., Rodellas, V., Santos-Echeandia, J., Tovar-Sánchez, A., GarciaSolsona, E., Masqué, P., 2016. Submarine groundwater discharge: A significant source of dissolved trace metals to the North Western Mediterranean Sea, Mar. Chem., 186, 90-100, http://dx.doi.org/10.1016/j.marchem.2016.08.004.

Turner, I., Masselink, G., 1998. Swash infiltration-exfiltration and sediment transport, J. Geophy. Res., 103 (C13), 30813-30824, http://dx.doi.org/10.1029/98JC02606.

Turner, I.L., Nielsen, P., 1997. Rapid water table fluctuations within the beach face: Implications for swash zone sediment mobility? Coast. Eng., 32 (1), 45-59, http://doi.org/10.1016/S03783839(97)00015-X. 
Turner, I.L., Rau, G.C., Austin, M.J., Andersen, M.S., 2016. Groundwater fluxes and flow paths within coastal barriers: Observations from a large-scale laboratory experiment (BARDEX II), Coast. Eng., 113, 104-116, 10.1016/j.coastaleng.2015.08.004.

Vandenbohede, A., Lebbe, L., 2005. Occurrence of salt water above fresh water in dynamic equilibrium in a coastal groundwater flow system near De Panne, Belgium, Hydrogeol. J., 14 (4), 462 - 472, https://doi.org/10.1007/s10040-005-0446-5.

Volker, R.E., Rushton, K.R., 1982. An assessment of the importance of some parameters for seawater intrusion in aquifers and a comparison of dispersive and sharp-interface modelling approaches, J. Hydrol., 56 (3), 239-250, http://dx.doi.org/10.1016/0022-1694(82)90015-4.

Vörösmarty, C.J., Green, P., Salisbury, J., Lammers, R.B., 2000. Global water resources: Vulnerability from climate change and population growth, Science, 289 (5477), 284-288, http://dx.doi.org/10.1126/science.289.5477.284.

Wang, G., Jing, W., Wang, S., Xu, Y., Wang, Z., Zhang, Z., Li, Q., Dai, M., 2014. Coastal acidification induced by tidal-driven submarine groundwater discharge in a coastal coral reef system, Environ. Sci. Technol., 48 (22), 13069-13075, http://dx.doi.org/10.1021/es5026867.

Wang, X., Li, H., Jiao, J.J., Barry, D.A., Li, L., Luo, X., Wang, C., Wan, L., Wang, X., Jiang, X., Ma, Q., Qu, W., 2015. Submarine fresh groundwater discharge into Laizhou Bay comparable to the Yellow River flux, Sci. Rep., 5, 8814, http://dx.doi.org/10.1038/srep08814.

Waska, H., Kim, G., 2010. Differences in microphytobenthos and macrofaunal abundances associated with groundwater discharge in the intertidal zone, Mar. Ecol. Prog. Ser., 407, 159172, https://doi.org/10.3354/meps08568. 
Weinstein, Y., Yechieli, Y., Shalem, Y., Burnett, W.C., Swarzenski, P.W., Herut, B., 2011. What is the role of fresh groundwater and recirculated seawater in conveying nutrients to the coastal ocean? Environ. Sci. Technol., 45 (12), 5195-5200, http://dx.doi.org/10.1021/es104394r.

Werner, A.D., Simmons, C.T., 2009. Impact of sea-level rise on sea water intrusion in coastal aquifers, Ground Water, 47 (2), 197-204, http://dx.doi.org/10.1111/j.1745-6584.2008.00535.x.

Werner, A.D., Bakker, M., Post, V.E.A., Vandenbohede, A., Lu, C., Ataie-Ashtiani, B., Simmons, C.T., Barry, D.A., 2013. Seawater intrusion processes, investigation and management: Recent advances and future challenges, Adv. Water Resour., 51, 3-26, http://dx.doi.org/10.1016/j.advwatres.2012.03.004.

Westbrook, S.J., Rayner, J.L., Davis, G.B., Clement, T.P., Bjerg, P.L., Fisher, S.J., 2005. Interaction between shallow groundwater, saline surface water and contaminant discharge at a seasonally and tidally forced estuarine boundary, J. Hydrol., 302 (1-4), 255-269, http://dx.doi.org/10.1016/j.jhydrol.2004.07.007.

Wilson, A.M., Evans, T.B., Moore, W.S., Schutte, C.A., Joye, S.B., 2015. What time scales are important for monitoring tidally influenced submarine groundwater discharge? Insights from a salt marsh, Water Resour. Res., 51 (6), 4198-4207, http://doi.org/10.1002/2014WR015984.

Windom, H.L., Moore, W.S., Niencheski, L.F.H., Jahnke, R.A., 2006. Submarine groundwater discharge: A large, previously unrecognized source of dissolved iron to the South Atlantic Ocean, Mar. Chem., 102, 252-266, http://dx.doi.org/10.1016/j.marchem.2006.06.016.

Wong, W.W., Grace, M.R., Cartwright, I., Cardenas, M.R., Zamora, P., Cook, P., 2013.

Dynamics of groundwater-derived nitrate and nitrous oxide in a tidal estuary from radon mass 
balance modeling, Limnol. Oceanogr., 58 (5), 1689-1706, http://dx.doi.org/10.4319/lo.2013.58.5.1689.

Xin, P., Robinson, C., Li, L., Barry, D.A., Bakhtyar, R., 2010. Effects of wave forcing on a subterranean estuary, Water Resour. Res., 46 (12), W12505, http://dx.doi.org/10.1029/2010WR009632.

Xin, P., Wang, S.S.J., Robinson, C., Li, L., Wang, Y.-G., Barry, D.A., 2014. Memory of past random wave conditions in submarine groundwater discharge, Geophys. Res. Lett., 41 (7), 24012410, http://dx.doi.org/10.1002/2014GL059617.

Xin, P., Wang, S.S.J., Lu, C., Robinson, C., Li, L., 2015. Nonlinear interactions of waves and tides in a subterranean estuary, Geophys. Res. Lett., 42 (7), 2277-2284, http://dx.doi.org/10.1002/2015GL063643.

Xin, P., Zhou, T., Lu, C., Shen, C., Zhang, C., D'Alpaos, A., Li, L., 2017. Combined effects of tides, evaporation and rainfall on the soil conditions in an intertidal creek-marsh system, $A d v$. Water Resour., 130, 1-15, http://dx.doi.org/10.1016/j.advwatres.2017.02.014.

Yang, J., Graf, T., Herold, M., Ptak, T., 2013. Modelling the effects of tides and storm surges on coastal aquifers using a coupled surface-subsurface approach, J. Contam. Hydrol., 149, 61-75, http://dx.doi.org/10.1016/j.jconhyd.2013.03.002.

Yechieli, Y., Shalev, E., Wollman, S., Kiro, Y., Kafri, U., 2010. Response of the Mediterranean and Dead Sea coastal aquifers to sea level variations, Water Resour. Res., 46 (12), W12550, http://dx.doi.org/10.1029/2009WR008708. 
Yu, X., Yang, J., Graf, T., Koneshloo, M., O'Neal, M.A., Michael, H.A., 2016. Impact of topography on groundwater salinization due to ocean surge inundation, Water Resour. Res., 52 (8), 5794-5812, http://doi.org/10.1002/2016WR018814.

Yu, X., Xin, P., Lu, C., Robinson, C., Li, L., Barry, D.A., 2017. Effects of episodic rainfall on a subterranean estuary, Water Resour. Res., 53 (7), 5774-5787, https://doi.org/10.1002/2017WR020809.

Zektser, I.S., Loaiciga, H.A., 1993. Groundwater fluxes in the global hydrologic cycle: Past, present and future, J. Hydrol., 144 (1), 405-427, http://dx.doi.org/10.1016/0022-1694(93)901829.

Zhang, C.M., Li, L., Lockington, D., 2014. Numerical study of evaporation-induced salt accumulation and precipitation in bare saline soils: Mechanism and feedback, Water Resour. Res., 50 (10), 8084-8106, https://doi.org/10.1002/2013wr015127.

Zhang, Q., Volker, R.E., Lockington, D.A., 2002. Experimental investigation of contaminant transport in coastal groundwater, Adv. Environ. Res., 6 (3), 229-237, http://doi.org/10.1016/S1093-0191(01)00054-5.

Zhang, Y., Li, L., Erler, D.V., Santos, I., Lockington, D., 2016. Effects of alongshore morphology on groundwater flow and solute transport in a nearshore aquifer, Water Resour. Res., 52 (2), 990-1008, http://dx.doi.org/10.1002/2015WR017420.

Zhao, S., Zhang, P., Crusius, J., Kroeger, K.D., Bratton, J.F., 2011. Use of pharmaceuticals and pesticides to constrain nutrient sources in coastal groundwater of northwestern Long Island, New York, USA, J. Environ. Monit., 13 (5), 1337-1343, https://doi.org/10.1039/C1EM10039D. 